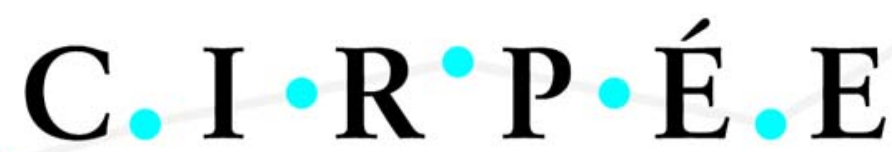 \\ Centre Interuniversitaire sur le Risque, les Politiques Économiques et l'Emploi
}

Cahier de recherche/Working Paper 10-13

\section{The Gender and Poverty Impacts of Trade Liberalization in Senegal}

\author{
John Cockburn \\ Erwin Corong \\ Bernard Decaluwé \\ Ismaël Fofana \\ Véronique Robichaud
}

Mars/March 2010

Cockburn: Corresponding author. Poverty and Economic Policy (PEP) Research Network and CIRPÉE, Université Laval jcoc@ecn.ulaval.ca

Corong: Centre of Policy Studies, Monash University

Decaluwé: Department of Economics, Université Laval, CIRPÉE and PEP

Fofana: Poverty and Economic Policy (PEP) Research Network

Robichaud: Poverty and Economic Policy (PEP) Research Network

Funding for this study was provided by the World Bank-Netherlands Partnership Program (BNPP) and the Poverty and Economic Policy (PEP) research network, which is financed by the Government of Canada through the International Development Research Centre (IDRC) and the Canadian International Development Agency (CIDA), and by the Australian Agency for International Development (AusAID). Our thanks to André Martens for his review of the empirical literature on trade, FDI and growth. We also thank Maurizio Bussolo, André Martens and Rafael de Hoyos for comments and suggestions. Acknowledgments to Joseph Cabral and Fatou Cissé for help in obtaining country data and information. 


\begin{abstract}
:
Developing countries are deeply engaged in trade negotiations at the bilateral, regional and international (WTO) levels. As imports, exports and tariff duties all occupy an important part of their economies, far-reaching impacts on production, labor and capital markets, household incomes and, perhaps most importantly, economic growth will indubitably ensue. As men and women occupy very different roles in these economies, particularly in terms of the import and export orientation of the sectors in which they work, they will be affected very differently by these reforms. To anticipate these changes, a dynamic economy-wide model is developed with an application to Senegal. Whereas most similar existing studies consider the comparative static resource reallocation effects of trade reforms, ours is the first to focus on the growth effects ("dynamic gains from trade"), which are thought to be possibly much larger.
\end{abstract}

The trade-productivity link is revealed to be the strongest growth channel, raising GDP by over three percentage points by the end of our 15 year simulation period.

Trade liberalization is found to increase the gender wage gap in favor of men, especially among unskilled workers, as men are more active in export-oriented sectors such as cash crops and mining whereas women contribute more to import-competing sectors such as food crops. Furthermore, the ensuing growth effects further widen the over-all gender wage gap, as the productivity gains from increased openness are greatest in female-intensive sectors in which imports rise markedly. Thus, this suggests the need to implement policies aimed at increasing both unskilled and skilled women's exposure in labor-intensive export industries, which is currently male dominated.

A linked microsimulation analysis, based on a survey of Senegalese households, show that trade liberalization reduces poverty in Senegal, particularly in rural areas. While the fall in the relative wages of rural workers would initially lead us to believe that rural households would lose the most from trade liberalization, they are in fact compensated by greater consumer price savings, given that they consume more goods from the initially protected agricultural and agro-industrial sectors.

Keywords: Senegal, Trade, Gender, Poverty, Growth

JEL Classification: C68, F17, F43, I32, J16, O24, O33, O55 


\section{Introduction}

Female participation in the labor market has increased significantly over the last decade, corresponding to a period of liberalization in most developing countries. Studies show that the feminization of work is greater in industrial sectors and in semi-industrialized economies, where export industries employ more women, than in agricultural sectors and economies ${ }^{2}$. In semiindustrial economies, liberalization reduces the overall gap between men and women in terms of wage rates, labor market participation and income distribution.

Existing research suggests that trade may favor women in industrial and semi-industrial economies, where women are more active in export-oriented sectors such as garments and light manufacturing. In contrast, in agricultural economies - and in agricultural sectors in (semi-) industrial economies - trade is found to favor men, as they are more likely to be engaged in the production of cash crops for export while women focus on import-competing food crops.

In the majority of African countries, female work constitutes the base of agricultural food production, which is generally import-competing and concentrated in small plots. In these economies, trade liberalization tends to favor male workers and owners of large landholdings, which are more conducive to cash crops for export, whereas female workers involved in food crop production face increased import competition. ${ }^{3}$

In Senegal, women work primarily in agriculture sector which occupies 77 percent of the Senegalese labour force. Women represent 43 percent of the total labour force and contribute for only 26 percent of employment in non agriculture sector. ${ }^{4}$ Although, the recent growth has contribute to reduce poverty by 11 percentage points between 1994 and 2002 (DSRP II, 2006) ${ }^{5}$, still well over half of the Senegalese population, 57 percent (DSRP II, 2006), lives in poverty. Moreover, the absolute number of poor has increased between 1994 and 2002 and many of them are women. ${ }^{6}$

Senegal is engaged in the process of liberalizing its external trade under various - unilateral, bilateral, and multilateral - trade negotiations. The import-substitution and export-subsidy policies adopted after independence were liberalized from 1980 onwards, in the context of various structural adjustment programs in the hope of encouraging more efficient resource allocation.

The 100 percent devaluation of the CFA franc in 1994 was an important step in this reform process. Senegal also joined the WTO in 1995 and, following the Uruguay round, consolidated its tariff rates around 30 percent. Quotas have been progressively eliminated and replaced by a temporary surtax on basic goods. In addition, Senegal reduced the level of domestic support to

${ }^{2}$ Elson and Pearson (1981), Standing (1989), Wood (1991), Cagatay and Ozler (1995), Joekes (1995 and 1999) and Ozler (2000 and 2001).

${ }^{3}$ Fontana et al. 1998

${ }^{4}$ Development Indicators database (at http://devdata.worldbank.org)

5 "Document de Stratégie pour la croissance et la Réduction de la Pauvreté, 2006-2010".

${ }^{6}$ The Senegalese population has grown by an average of 2.5 percent over the period of 1994 and 2002 ; World Development Indicators database (at http://devdata.worldbank.org) 
agricultural products. At the regional level, Senegal is a founding member of the Economic Community of Western African States (known as CEDEAO), which has the objective of freer trade at the regional level and the creation of a Common External Tariff (CET).

Since 1994 trade liberalization has been reinforced under the Western African Economic and Monetary Union (known as UEMOA) reforms. The objectives of the latter are: the convergence of economic policies and performances of its members; the creation of a customs union; the coordination of sectoral policies. Senegal adopted the UEMOA's Common External Tariff (CET) in January 2000. Thus, all goods entering the customs territory of any UEMOA country, are assessed the same rate of customs duty. ${ }^{7}$ In 2003, CEDEAO and UEMOA began negotiating an Economic Partnership Agreement (EPA) with the European Union. At the end of the process (2024), it is expected that Senegal will liberalize nearly $80 \%$ of total imports from Europe and be granted free access to the European market. Furthermore, Senegal is negotiating new trade agreements with Tunisia, Morocco and Egypt in the context of UEMOA.

In spite of the fact that Senegal, as a less developed country (LDC), has benefited from access to the European and North American markets for products such as textiles, and its increasing participation in different trade agreements, its exports are not expanding significantly. This appears to be due to high production costs and low product quality that makes Senegalese exports less competitive on the world market. Moreover, the domestic support and subsidies for European farmers and strict European quality norms represent serious restrictions to access.

The study aims at contributing to the debate on the gender and poverty implications of trade liberalization in the context of Senegal economy. Furthermore, it explores the distribution of the dynamic gains from trade between men and women.

There is strong evidence that openness to international trade creates a more competitive environment, and stimulates the diffusion of new technologies, innovation, the adoption of new methods of production and an increase in the availability of imported inputs. ${ }^{8}$ All of these factors lead to important productivity and efficiency gains. It is also argued that in the presence of firm heterogeneity, increased trade will lead to a rationalization of output toward the most productive firms ${ }^{9}$. Moreover, considerable evidence suggests that increased openness also directly favors foreign direct investment ${ }^{10}$. There is also an important debate concerning the poverty impacts of growth: pro-poor growth.

\footnotetext{
${ }^{7}$ The new legislation set out the four rates: 0 percent on pharmaceuticals, agricultural inputs, capital goods, computer and data processing equipment not produced locally, and social, cultural, and scientific goods; 5 percent on raw materials, crude oil, and grains for industries; 10 percent on semi-finished products, diesel/fuel oil, intermediate goods and other grains; 20 percent on goods for final consumption, capital goods and computer and data processing equipment already available through local production, new and used vehicles. A statistical fee of 1 percent is levied on imported goods, as well as uniform taxes of 1 percent for UEMOA and 0.5 percent for CEDEAO to finance these two regional institutions.

${ }^{8}$ For a compact elaboration on these issues see Kim (2000), Keller (2000), and Winters (2004).

${ }^{9}$ For important contributions in this area see, among others, Melitz (2003), Bernard et al. (2003), Helpman et al. (2004), Baldwin (2005), Baldwin and Robert-Nicoud (2006), and Gustafsson and Segerstrom (2007).

${ }^{10}$ This discussion is based on Martens (2008a).
} 
The poverty impacts of growth depend on the specific nature of that growth and the motors driving it. Growth driven by agricultural productivity gains is likely to have vastly different poverty impacts than growth driven by an increase in the prices of a country's mineral resources. In the same way, the growth impacts of trade liberalization will depend on the initial tariff structure, the composition of a country's imports and exports, and the participation of the poor in these sectors.

Yet, the analytical tool most suited to opening this black box to track the channels of influence computable general equilibrium (CGE) models - are typically restricted to a static framework in which poverty impacts result solely from a short term reallocation of resources and growth is not even considered. Thus it is not very that they generally find relatively small welfare and poverty impacts of trade liberalization.

In this paper, we bring the lessons from the broader trade-growth-poverty literature into the CGE framework. The CGE viewpoint in turn allows us to identify and explore in more depth the exact mechanisms and channels through which trade liberalization contributes to the growth process and poverty reduction. In particular, we contrast the short-run and long-run impacts on the economy, welfare and poverty using a sequential dynamic general equilibrium model applied to Senegal. We place particular emphasis on bringing out the gender differences in the direct and growth effects of trade liberalization, particularly in terms of the gender wage gap ${ }^{11}$.

We apply our framework to the specific case of a complete trade liberalization policy in Senegal. The remainder of this paper is as follows. First, we present a brief overview of the Senegalese context: trade policies, poverty and gender aspects. We then present a short review of the literature on the links between trade, growth, gender and poverty. In section three, we present the salient characteristics of our model before analyzing the impacts of our simulation of complete trade liberalization in Senegal in section four. Section five concludes.

\section{Gender, Poverty and Trade in Senegal: A review}

The process of trade liberalization in Senegal takes place in a context of economic reforms under the Poverty Reduction and Growth Facility (PRGF) program of the International Monetary Fund and the World Bank quoted in the Poverty Reduction Strategy Papers (PRSP). The PRSP is a roadmap describing the Government programs and measures to be implemented for the reduction of poverty as presented by the Millennium Development Goals, among others, eradicate extreme poverty and hunger, and promote gender equality and empower women.

The Senegalese economy posted a stable and sustained annual growth rate of 5 percent following the 1994 CFA franc devaluation. The improvement of the budgetary situation and the boom in public investment, followed by an increase in private investment, were the main sources of growth over the past decade (Azam, Dia and Tsimpo, 2005). Higher investment created higher growth, which in turn contributed to a reduction in poverty. Indeed, poverty fell by 10.8

\footnotetext{
${ }^{11}$ Other possible gender effects involve labor market participation, adjustments in the time devoted to domestic work and leisure, bargaining power and the intra-household allocation of resources, although we focus only on the wage channel in this analysis.
} 
percentage points - from 67.9 percent to 57.1 percent - between 1994 and 2002, although this still represents well over half of the Senegalese population. More recently, 64 per cent of interviewed households noted an increase of poverty over the last five years (DRSP II, 2006). Furthermore, recent growth has been found to be neither pro-rural nor pro-poor in Senegal, creating an increase in inequality (Azam et al., 2005). Therefore, as recent studies (Dollar and Kraay, 2001 and IBRD/World Bank, 2005) point out, growth is a necessary, but not sufficient, condition for poverty reduction in Senegal.

In 2001/02, female-headed households were found to have a lower incidence of poverty than their male counterparts: 37 and 51 per cent, respectively (DRSP II, 2006). Badji and Daffé (2004) argue that the number of poor female-headed households increased between 1991/92 and 1994/95. In contrast, Badji and Boccanfuso (2006) found a substantial drop of this proportion between 1994/95 and 2001/02, from 55.0 to 37.0 percent. The proportion of male-headed households under the national poverty line has also dropped during the same period, from 62.6 to 51.0 percent. The decline of poverty among female-headed households is less dramatic in Dakar, than in other urban and rural areas. The poorest are headed be females with little or no education. The proportion of poor female headed-households fell between 1994/95 and 2001/02, regardless of their level of schooling according to Badji and Buccanfuso (2006), although the drop was greater for women with low levels of education i.e. those not reaching secondary school. This suggests that the poverty reduction programs may have affected low-educated women more than their higher educated counterparts.

Several past studies have looked at the impacts of trade liberalization in Senegal.

Ezenwe (1982) found that many low-income countries in West Africa experienced slower growth and industrialization in the 1970s than the 1960s, as they adopted an import substitution strategy that restricted the growth in trade. In contrast, middle-income developing countries increased their export and posted better growth performance. Senegal was among the latter group of countries and experienced an expansion in trade and strong economic growth.

Boccanfuso, Cabral, Cissé, Diagne and Savard (2003) suggest that 50 percent increase of international prices of grains will likely increase poverty in Senegal. High poverty increase will be observed in urban than rural areas and educated household head in Dakar and in rural areas will be worse off. The price increase of cereal negatively impact agriculture and food manufacturing; labor income of unskilled workers deteriorate while skilled workers are better off.

Fofana, Cockburn, Decaluwe, Diagne, Cissé and Cabral (2005) integrate all households from a national representative survey of the population into a CGE model and show that unilateral tariff reduction will not contribute, at least in the short term, to reduce poverty, in particular in rural areas where the highest poverty levels are observed. The reform will not benefit rural poor because of their high dependency to agriculture income and consumption, as well as the low share of imported commodities in the rural households' consumption basket. They found that the traditional character - less intensive in imported inputs - and the lack of export opportunities limit the possibility of agriculture to cope with higher competition of imports induced by the trade reform. 
Annabi, Cissé, Cockburn and Decaluwé (2005) analysed the relationship between trade, growth and poverty in Senegal. They conclude that the elimination of tariffs on all imports would likely have strong growth and poverty reduction impacts in the long run and also reduce poverty in the short run. They also found that full liberalization worsens income distribution in Senegal with greater gains among urban dwellers and the non-poor.

Maertens and Swinnen (2006) on trade, standards, and poverty in Senegal argue that enhancing quality and safety standards will not constitute a barrier for trade and poverty reduction in Senegal. They show that high-standards trade, although contributing to switch production from smallholder contract-based farming to large-scale integrated estate production will "mainly altered the mechanism through which poor households benefit: through labor markets instead of product markets”. These changes had a stronger poverty reduction impact in Senegal through the labor market mechanism as workers moved from small-contract farming to large-scale farms.

Cockburn, Decaluwé and Robichaud (2007) bring together lessons drawn from the CGE analysis of the impacts of trade liberalization on poverty in Bangladesh, Benin, India, Nepal, Pakistan, the Philippines and Senegal. They found that unilateral tariff reduction increases welfare and reduces poverty; the reform is pro-urban and may increase rural poverty as non agriculture sectors benefit relatively more than agriculture sectors.

While increased trade might benefit Senegal as a whole, there is a growing concern about it distributional impacts between poor and non-poor. Although the assessment of the impacts of trade liberalization on the Senegalese economy and population has received some interest in the literature, none of the previous analysis has focused on the distributional impacts between men and women. Moreover, the only trade-related motors of growth accounted for (Annabi et al., 2005) are the reduction in the cost of imported investment goods and the reallocation of income between households with different savings rates.

\section{Analytical framework}

Dynamic computable general equilibrium (CGE) models can be classified as intertemporal or sequential (recursive). Intertemporal dynamic models are based on optimal growth theory where the behavior of economic agents is characterized by perfect foresight. In a number of circumstances, and particularly in a developing country, it is hard to assume that agents have perfect foresight. For this reason we believe that it is more appropriate to develop a sequential dynamic CGE model. In this kind of dynamics agents have myopic behavior. To the extent that the investment decisions are truly forward-looking, reality is probably somewhere between these two extreme hypotheses.

A sequential dynamic model is basically a series of static CGE models that are linked between periods by behavioral equations for endogeneous variables and by updating procedures for exogenous variables. Capital stock is updated endogenously with a capital accumulation equation, whereas population (and total labor supply) is updated exogenously between periods. It is also possible to add updating mechanisms for other variables such as public expenditure, 
transfers, technological change or debt accumulation. Below we present a description of the static and dynamic aspects of the model. We focus our discussion on the new characteristics of the model and those most relevant to the gender-trade-growth nexus, the rest being standard for most CGE models. A complete list of equations and variables is presented in annex 4.

\subsection{Activities}

On the production side we assume that in each sector there is a representative firm that generates value added by combining labor and capital. We adopt a nested structure for production. Sectoral output $X S_{i, t}$ is a Leontief function of value added $V A_{i, t}$ and total intermediate consumption $C I_{i, t}$. Value added is in turn represented by a CES function of unskilled labor $L N Q_{i, t}$ and a composite factor $K L Q_{i, t}$, which is in itself a CES function of capital $K D_{i, t}$ and skilled labor $L Q_{i, t}$. We assume that the degree of substitutability is lower between capital and skilled labor than between the composite capital factor and unskilled workers. The basic intuition is that, for a given technology, any increase in capital intensity requires an almost proportionate increase in skilled labor. Thus, in this way, capital accumulation is "skilled biased", increasing the demand for skilled versus unskilled labor. In this context, the lack of skilled labor could be one of the factors limiting the growth process (equation numbers refer to the full model specification provided in Annex 1):

$$
\begin{aligned}
& X S_{i, t}=V A_{i, t} / v_{i} \\
& C I_{i, t}=i o_{i} \cdot X S_{i, t} \\
& V A_{i, t}=A_{i}^{V A} \cdot \theta_{i, t} \cdot\left(\alpha_{i}^{V A} \cdot L N Q_{i, t}^{-\rho_{i}^{V A}}+\left(1-\alpha_{i}^{V A}\right) \cdot K L Q_{i, t}^{-\rho_{i}^{V A}}\right)^{-1 / \rho_{i}^{V A}} \\
& K L Q_{i, t}=A_{i}^{K L} \cdot\left(\alpha_{i}^{K L} \cdot L Q_{i, t}^{-\rho_{i}^{K L}}+\left(1-\alpha_{i}^{K L}\right) \cdot K D_{i, t}^{-\rho_{i}^{K L}}\right)^{-1 / \rho_{i}^{K L}}
\end{aligned}
$$

All variables have a sector index $\mathrm{i}$ and a time index $\mathrm{t}$, as the model is solved recursively over the entire period of analysis.

\subsection{Labor}

We again follow a nested structure for the composition of the different types of labor. On a first level, among skilled workers ( $\left.L Q_{i, t}\right)$, we assume that there is imperfect substitutability between urban $\left(L D T_{U N Q, i, t}\right)$ and rural workers $\left(L D T_{R N Q, i, t}\right)$. The same assumption is adopted for unskilled workers $\left(L N Q_{i, t}\right)$, which we assume to be composed of imperfectly substitutable urban $\left(L D T_{U Q, i, t}\right)$ and rural workers $\left(L D T_{R Q, i, t}\right)$ :

$$
\begin{aligned}
& L N Q_{i, t}=A_{i}^{L N Q} \cdot\left(\alpha_{i}^{L N Q} \cdot L D T_{U N Q, i, t}^{-\rho_{i}^{L N Q}}+\left(1-\alpha_{i}^{L N Q}\right) \cdot L D T_{R N Q, i, t}^{-\rho_{i}^{L N Q}}\right)^{-1 / \rho_{i}^{L N Q}} \\
& L Q_{i, t}=A_{i}^{L Q} \cdot\left(\alpha_{i}^{L Q} \cdot L D T_{U Q, i, t}^{-\rho_{i}^{L Q}}+\left(1-\alpha_{i}^{L Q}\right) \cdot L D T_{R Q, i, t}^{-\rho_{i}^{L Q}}\right)^{-1 / \rho_{i}^{L Q}}
\end{aligned}
$$


At a second level, among skilled and unskilled rural and urban workers, we assume that male $M L D T_{l, i, t}$ and female workers $F L D T_{l, i, t}$ are also imperfect substitutes.

$$
L D T_{l, i, t}=A_{l, i}^{L G} \cdot\left(\alpha_{l, i}^{L G} \cdot F L D T_{l, i, t}^{-\rho_{l, i}^{L G}}+\left(1-\alpha_{i}^{L G}\right) \cdot M L D T_{l, i, t}^{-\rho_{l, i}^{L G}}\right)^{-1 / \rho_{l, i}^{L G}}
$$

From these equations, we can derive the demand equations for each of the factors of production $^{12}$. Finally, the market equilibrium conditions determine factor and product prices ${ }^{13}$. In particular, we assume that all labor markets clear:

$$
\begin{aligned}
& \sum_{H} M L S_{h, l, t}=\sum_{I} M L D T_{l, i, t} \\
& \sum_{H} F L S_{h, l, t}=\sum_{I} F L D T_{l, i, t}
\end{aligned}
$$

where $F L S_{h, l, t}\left(M L S_{h, l, t}\right)$ is the household endowment in female (male) labor of type L. Total male and female labor supply are assumed to increase at the exogenous population growth rate. Data constraints prevented us from breaking down rural workers by skill level in Senegal. In Uganda, a rural/urban disaggregation was impossible, although the skill disaggregation distinguishes elementary workers, who are even less skilled than unskilled workers.

Some limits of the current analysis merit discussion. First, we assume that the unemployment rate is fixed and that labor market participation rates are fixed. Consequently, the main gender impact of trade liberalization is seen through wage effects. While this is a serious limitation to our analysis to be addressed in future research, as labor demand is driving all of these effects, the results would not change qualitatively. For example, where trade liberalization is found to be pro-female, we would expect to see an increase in female labor market participation and a fall in their unemployment rates, which would both moderate female wage gains. However, they would also likely further boost growth effects. Furthermore, we do not explore the impacts of changes in female income shares on their bargaining power and the resulting intra-household allocation of resources. Other gender impacts of trade identified in the literature would also merit exploration in future research: reduced gender wage discrimination in the face of increased competition (Becker, 1959), skilled- (or gender-) biased technological progress, etc.

\subsection{Households and government}

Households earn their income $\left(\mathrm{YH}_{\mathrm{h}, \mathrm{t}}\right)$ from the remuneration of their production factors: female and male labor income and their share of the total returns to capital. They also receive dividends $\left(D I V_{h, t}\right)$, government transfers $\left(T G_{h, t}\right)$ and remittances from abroad $\left(T R O W_{-} H_{h, t}\right)$ :

\footnotetext{
12 See equations 6, 8, 10, 12, 13, 14 in Appendix 1.

${ }^{13}$ See equations 37, 38, 39, 40, 41, 42 in Appendix 1.
} 


$$
\begin{aligned}
Y H_{h, t} & =\sum_{L}\left(w f_{l, t} \cdot F L S_{h, l, t}+w m_{l, t} \cdot M L S_{h, l, t}\right)+\left(K H_{h, t} / K S_{t}\right) \cdot \sum_{I} r_{i, t} \cdot K D_{i, t} \\
& +P I N D E X_{t} \cdot T G_{h, t}+D I V_{h, t}+e_{t} \cdot T R O W_{-} H_{h, t}
\end{aligned}
$$

where $w f_{l, t}\left(w m_{l, t}\right)$ is the wage rate for female (male) workers of type $\mathrm{L}$ and $r_{i, t}$ is the sectoral rate of returns to capital. Thus, we can see that the distributional impacts of trade and growth will channel in part through their impacts on factor returns and the relative endowments of each household category in these factors.

Household demand for goods and services is derived from a Cobb-Douglas utility function after deduction of savings and direct taxes to the government ${ }^{14}$. Household savings and capital accumulation are discussed below in the "Motors of growth" section.

The only "non-traditional" aspect of our modeling of government is the assumption that the government deficit (surplus) is a constant share of the GDP:

$$
S G_{t}=\frac{S G^{0}}{G D P^{0}} \cdot G D P_{t}
$$

\subsection{Dynamics}

In every period the sectoral capital stocks $\left(K D_{i, t+1}\right)$ is updated with a capital accumulation equation involving the rate of depreciation $(\delta)$ and investment by sector of destination $I N D_{i, t}$. This equation describes the law of motion for the sectoral capital stock. It assumes that stocks are measured at the beginning of the period and that the flows are measured at the end of the period. New investments are allocated between the different sectors through an investment demand function that is similar to Bourguignon et al. (1989), and Jung and Thorbecke (2003) ${ }^{15}$. The capital accumulation rate - the ratio of investment to capital stock - is increasing with respect to the ratio of the rate of return to capital $r_{i, t}$ and its user cost $U_{t}$. The user cost is equal to the dual price of investment ( $\left.P K_{t}\right)$ multiplied by the sum of the depreciation rate and the interest rate $i r$. The elasticity of the rate of investment with respect to the ratio of return to capital and its user cost is assumed to be equal to 2 . The sum of investments by sector of destination is equal to total investment (IT), which is, in turn, determined by total savings.

$$
\begin{aligned}
K D_{i, t+1} & =K D_{i, t}(1-\delta)+I N D_{i, t} \\
\frac{I N D_{i, t}}{K D_{i, t}} & =\phi_{i}\left[\frac{r_{i, t}}{U_{t}}\right]^{\sigma_{i}^{K}}
\end{aligned}
$$

\footnotetext{
${ }^{14}$ See equations 17, 31 and 33 in Appendix 1.

${ }^{15}$ See for example the work by Lemelin and Decaluwe on investment demand equations. Abbink, Braber and Cohen (1995) use a sequential dynamic CGE model for Indonesia where total investment is distributed as a function of base year sectoral shares in total capital remuneration and sectoral profit rates.
} 


$$
\begin{aligned}
& U_{t}=P K_{t} \cdot\left(i r_{t}+\delta\right) \\
& I T_{i}=P K_{t} \cdot \sum_{I} I N D_{i, t}
\end{aligned}
$$

All inter-agent transfers in the model increase at the exogenous population growth rate. The exogenous dynamic updating of the model includes variables like transfers and volumes like government expenditures or minimum consumption of household that are indexed to relevant price indices ${ }^{16}$. The model is formulated as a static model that is solved recursively over a 15year time horizon ${ }^{17}$. The model is homogenous in prices and the exchange rate is the numéraire in each period.

\subsection{Motors of growth}

\section{a) Capital good prices}

The most immediate motor of growth in our model is the reduction in the cost of imported investment goods and, through import competition, their domestically-produced counterparts. This brings down the investment good price index and, consequently, increases total investments (equation 67 above) and capital accumulation (equation 68), where the investment good price index is given by:

$$
P K_{t}=\prod_{i}\left(P C_{i, t} / \mu_{i}\right)^{\mu_{i}}
$$

\section{b) Differential household savings rates}

A second channel in our core dynamic model stems from difference in the marginal propensities to save between household categories. If a shock leads to a redistribution of income towards household with high savings rates, this will increase capital accumulation and growth at the expense of current consumption. Of course, the opposite is true if redistribution favors the big spenders.

In addition to these "standard" motors of growth, we have introduced a number of other motors of growth that appear prominently in the econometric literature on growth.

\section{c) Technological progress and efficiency}

The impacts of increased openness on technological progress and productive efficiency at the sectoral level are captured by a parameter $\left(\theta_{i, t}\right)$ in the value added function. This is, in turn, a function of the change in the degree of openness of the sector relative to the base year (superscript 0). We measure the degree of openness as the sum of sectoral imports $\left(I M_{m, t}\right)$ and exports $\left(E X_{x, t}\right)$ as a percentage of sectoral output $X S_{i, t}{ }^{18}$.

\footnotetext{
${ }^{16}$ See equations 73 to 82 in the appendix 1

17 The model is formulated as a system of non linear equations solved recursively as a non-linear programming system (NLP) with GAMS/Conopt3 solver.

${ }^{18}$ The index $\mathrm{m}(\mathrm{x})$ represents the subset of importable (exportable) sectors.
} 
$\theta_{i, t}=\left[\frac{\left(I M_{i, t}+E X_{i, t}\right) / V A_{i, t}}{\left(I M_{i}^{0}+E X_{i}^{0}\right) / V A_{i}^{0}}\right]^{\sigma^{p T}}$ or $\theta_{i, t}=1$ if $E X_{i}^{0}=I M_{i}^{0}=0$

Based on a review of the empirical literature commissioned in the context of this study, the elasticity of productivity with respect to openness ranges roughly between 0.34 and $0.74^{19}$. We have adopted an elasticity of 0.5 .

Other formulations are possible. In the empirical literature, the focus is often solely on import penetration ratios, often restricted to imports from developed countries, as the principal channel of influence of trade on productivity. This will be the subject of further research.

\section{d) Foreign investment}

We assume that trade liberalization creates an environment that favors the investment of foreign savings in Senegal. First, foreign investors are more attracted by an open economic environment, which we capture by including an economy-wide openness index in the determination of the current account balance, which is equal to foreign savings invested in Senegal ${ }^{20}$. Second, to the extent that trade liberalization increases the returns to capital, this will further increase net capital inflows (CAB) from abroad:

$C A B_{t}=\frac{C A B^{0}}{G D P^{0}} \cdot\left[\frac{\text { rmoy }_{t} / \text { PINDEX }_{t}}{r m o y^{0} / \operatorname{PINDEX}^{0}}\right]^{\sigma^{F S R}} \cdot\left[\frac{\left(I M_{t}+E X_{t}\right) / G D P_{t}}{\left(I M^{0}+E X^{0}\right) / G D P^{0}}\right]^{\sigma^{F S O}} G D P_{t}$

As a percentage of GDP (the sum of sectoral value added), the current account deficit will increase with respect to its base value if the average rate of return on capital $\left(\right.$ rmoy $_{t} /$ PINDEX $\left._{t}\right)$ or the economy-wide degree of openness $\left((I M+E X) / G D P\right.$ increases. ${ }^{21}$ Based on a review of the empirical literature commissioned for this study ${ }^{22}$, we adopt an estimate of 0.04 for the elasticity of substitution of foreign investment with respect to openness and 0.5 with respect to the rate of return to capital.

Note that several other formulations could be considered. First, the above relationship could be restricted to FDI alone, assuming that all other elements of the capital and financial accounts of the balance of payments are, for example, a fixed proportion of GDP. Second, it is likely that FDI (or all net foreign capital inflows) are, at least to some extent, sector-specific. It would be possible to apply the above equations at a sectoral level, where FDI in a given sector would depend on the sectoral returns to capital and the sectoral openness index.

\footnotetext{
19 See Martens (2008b). For empirical studies see, for example, Jonsson and Subramanian (2001) and Arora and Bhundia (2003), both focusing on South Africa.

${ }^{20}$ Note that the causality may also be inversed. As trade and foreign investment are determined simultaneously in a CGE model, what is important is that they are complements, rather than substitutes.

${ }^{21}$ See equations 50 and 51 in Appendix 1

22 See Martens (2008a).
} 


\section{e) Endogenous household savings rates}

In static CGE models, the savings behavior of households is generally very simple. The saving rate is a simple parameter measuring either the average or the marginal saving rates of each household category. We enrich this framework by assuming that household savings rates are sensitive with respect to changes in the real rate of returns to capital. More specifically we define the following equation:

$$
S H_{h, t}=\psi_{h} \cdot\left[\frac{\text { mmoy }_{t} / \text { PINDEX }_{t}}{\text { rmoy }^{0} / \operatorname{PINDEX}^{0}}\right]^{\sigma_{h}^{H S}} \cdot Y D H_{h, t}
$$

Over time, the relative capital endowments of each representative household change according to their savings. Households with a higher savings rate will have a faster growing capital stock and will consequently earn a growing share of total capital income generated in the economy. In particular, after depreciation, the capital stock belonging to household $\mathrm{h}$ will increase according to their savings:

$$
K H_{h, t+1}=K H_{h, t}(1-\delta)+\left(\frac{S H_{h, t}}{P K_{t}}\right)
$$

where PKt is the investment price index. All other agents accumulate capital in the same way:

$$
\begin{aligned}
& \text { irms: } K F_{t+1}=K F_{t}(1-\delta)+\left[\frac{S F_{t}}{P K_{t}}\right] \\
& \text { - } \\
& \text { est of world: } K R O W_{t+1}=K R O W_{t}(1-\delta)+\left(\frac{C A B_{t}}{P K_{t}}\right) \\
& \text { - } \\
& \text { overnment: } K G_{t+1}=K G_{t}(1-\delta)+\left[\frac{S G_{t}}{P K_{t}}\right]
\end{aligned}
$$

and all agents receive a share of total returns to capital equal to their share in the capital stock.

\subsection{Data}

The study uses the 2004 Social Accounting Matrix (SAM) ${ }^{23}$ elaborated from the Supply and Use Table (SUT) ${ }^{24}$ for the same year. The matrix includes 35 industries (six primary, 19 industrial and 10 in services), eight productive factors, and one representative household. Gender (male and female), geographical (urban and rural), and skill (educated and uneducated) dimensions are used to break down labor into six categories. Formal and informal capital are also presented in the SAM; the former is defined as the physical capital owned by corporations, while the latter represents the physical capital used in individual and household enterprises

\footnotetext{
${ }^{23}$ Fofana and Cabral (2007)

${ }^{24}$ Made available by the Senegalese National Statistical and Demographic Agency «Agence Nationale de la Statistique et de la Démographie».
} 
The SAM explicitly presents trade and transport margins, which appear as intermediate demands for the trade and transport sectors. It also provides detailed information on transfers (received and sent) for all household categories. Domestic tax receipts and import duties are also indicated, allowing us to undertake our trade policy experiments.

\subsection{Microsimulation model}

Following Ravallion and Loksin (2004), we build a simple non behavioral (micro accounting) microsimulation model in order to obtain a first-order approximation of the poverty impacts of full trade liberalization in Senegal over the full 15-year simulation period. Underlying data are obtained from the 2001/2002 Senegalese household survey ("Enquête Sénégalaise Auprès des Ménages 2”). Household consumption data are aggregated according to the 35 product categories appearing in the CGE model. On the income side, household capital endowments are grouped into agriculture and non agriculture capital, as in the CGE model. In the same way, labor incomes are grouped according to the location (rural vs. urban), sex (male vs. female) and skill level (skilled vs. unskilled) of workers. The structure of other expenditures (taxes and transfers to other households and to the rest of the world) and income (transfers from other households and from the rest of the world) are also grouped to correspond to the structure in the CGE model. The average tax and saving rates of households are taken from the CGE-model, but the microsimulation model adds a fixed household specific savings and tax parameter to capture household heterogeneity.

The variations in all factor prices generated by the CGE simulations are then used to calculate income variations for all households. Given fixed average savings and income tax rates and the average variation in all net transfers (which are simply indexed to an economy-wide price index), we then calculate the change in total consumption for each household. Consumption values are finally deflated by the change in household-specific consumption price indices (CPI), which are weighted by the budget share of each product in the household's total consumption. The poverty line used in 143,445 FCFA and is kept constant as we already deflate consumption values by the CPIs. Base year and post-simulation values for household consumption are then used to calculate corresponding poverty and inequality measures.

\section{Simulation Scenario and results}

The study simulates a unilateral complete elimination of import duties in Senegal. Although the magnitude of this import liberalization scenario is unlikely to be implemented in Senegal, in the absence of clear trade-liberalization agenda, one can take this policy shock as an upper bound of the likely impacts of import liberalization in Senegal.

The government makes up its lost tariff revenue through the introduction of a uniform compensatory sales tax that is endogenously determined in order to keep the public deficit constant as a share of GDP; this sales tax is roughly 2 percent. We focus first on the short-term (first year) effects, before noting any substantial differences in the long-term (last year) effects. 
Before, looking at the simulation results, some key characteristics of international trade in Senegal are provided in Table 1. Note, first, that the service sector represents almost 60 percent of value added in Senegal. In terms of international trade, it is clearly the industrial sector that is likely to be the most directly affected by the removal of import tariffs given that the overwhelming majority of imports are industrial, import intensities are highest in this sector and these imports initially face the highest tariff rates. For the same reason, the primary sector is likely to be more directly affected than the service sector. At the same time, the industrial sector also appears poised to benefit most from any ensuing export expansion, with over half of all exports and the highest export intensities, although it is closely followed by the service sector. The primary sector appears least likely to take advantage of export opportunities.

The distribution of male and female labor income is presented in Table 2. At the national level, the labor earnings of men are twice higher than of women, as men are more active in the labor market than women. The gender labor earnings gap is lower in Primary sector, but increases substantially in the secondary sector. Thus, putting together figures presented in tables 1 and 2 one would expect that the import liberalization shock performed in this study is likely to affect differently men and women in Senegal.

Table 1: Key characteristics of external trade (percent)

\begin{tabular}{lrlrrrr} 
& \multicolumn{3}{l}{ Share } & & \multicolumn{2}{c}{ Ratio } \\
& Value & & & Imports/ & Exports/ & Tariff \\
added & Imports & Exports & Consumption & Output & rates \\
Primary & 15.7 & 19.3 & 9.3 & 26.2 & 8.5 & 7.1 \\
Secondary & 25.7 & 72.9 & 54.5 & 44.4 & 18.6 & 16.7 \\
Tertiary & 58.6 & 7.8 & 36.2 & 8.4 & 18.1 & 0.0 \\
All & $\mathbf{1 0 0 . 0}$ & $\mathbf{1 0 0 . 0}$ & $\mathbf{1 0 0 . 0}$ & $\mathbf{3 0 . 9}$ & $\mathbf{1 8 . 4}$ & $\mathbf{1 3 . 6}$ \\
Source: SAM 2004 & & & & & &
\end{tabular}

Table 2: Distribution of male and female labour earnings (percent)

$\begin{array}{lrrr} & \text { Male } & \text { Female } & \text { All } \\ \text { Primary } & 57.5 & 42.5 & 100.0 \\ \text { Secondary } & 88.3 & 11.7 & 100.0 \\ \text { Tertiary } & 65.9 & 34.1 & 100.0 \\ \text { All } & \mathbf{6 7 . 8} & \mathbf{3 2 . 2} & \mathbf{1 0 0 . 0}\end{array}$

Source: SAM 2004

\section{a. Short-run effects}

The gender-specific analysis presented in figure 1 indicates that import liberalization increases the over-all gender wage gap, albeit marginally. This increase is more pronounced in urban than rural areas, where skilled (female and male) workers witness a higher increase in their real wage than their unskilled counterparts. The gender wage gap falls for skilled workers while it increases for unskilled workers. The gender gap increases among unskilled workers, whereas it diminishes among skilled workers. Our poverty analysis confirms that households experience a fall in poverty, far more among other urban households than Dakar and rural households. Indeed, poverty falls more among male-headed households relative to their female counterparts. In next, 
we track the channel by which men and women are impacted by the full removal of import duties.

Figure 1: Change in real wage rates (percent)

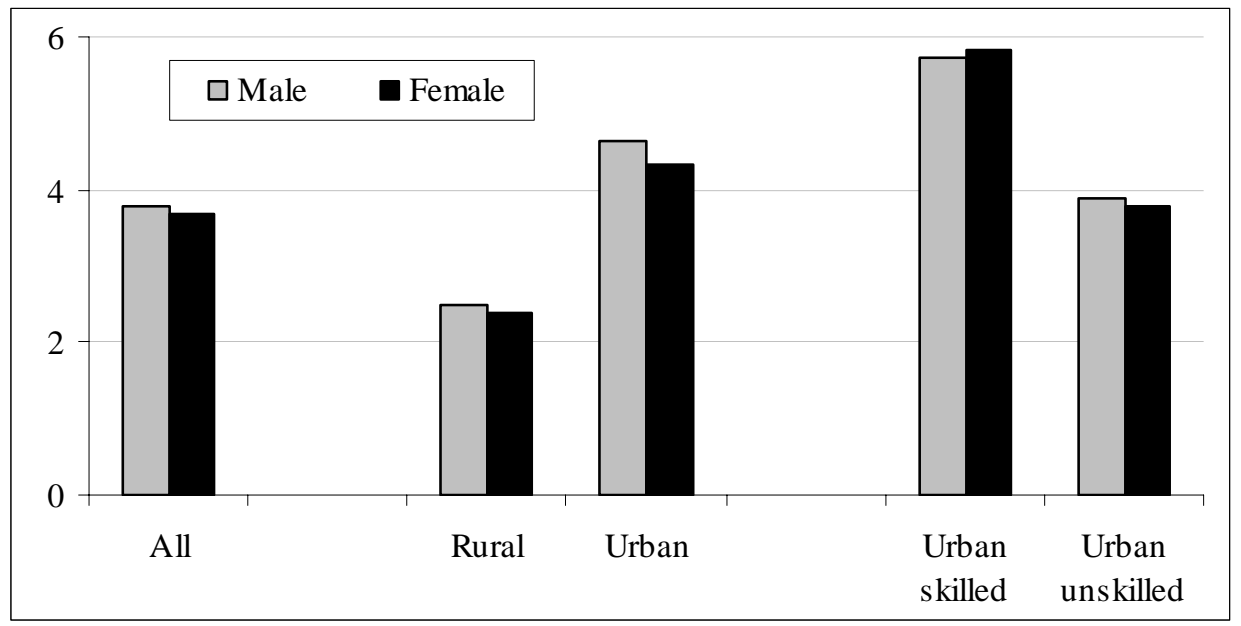

Figure 2: Change in poverty incidence (percent)

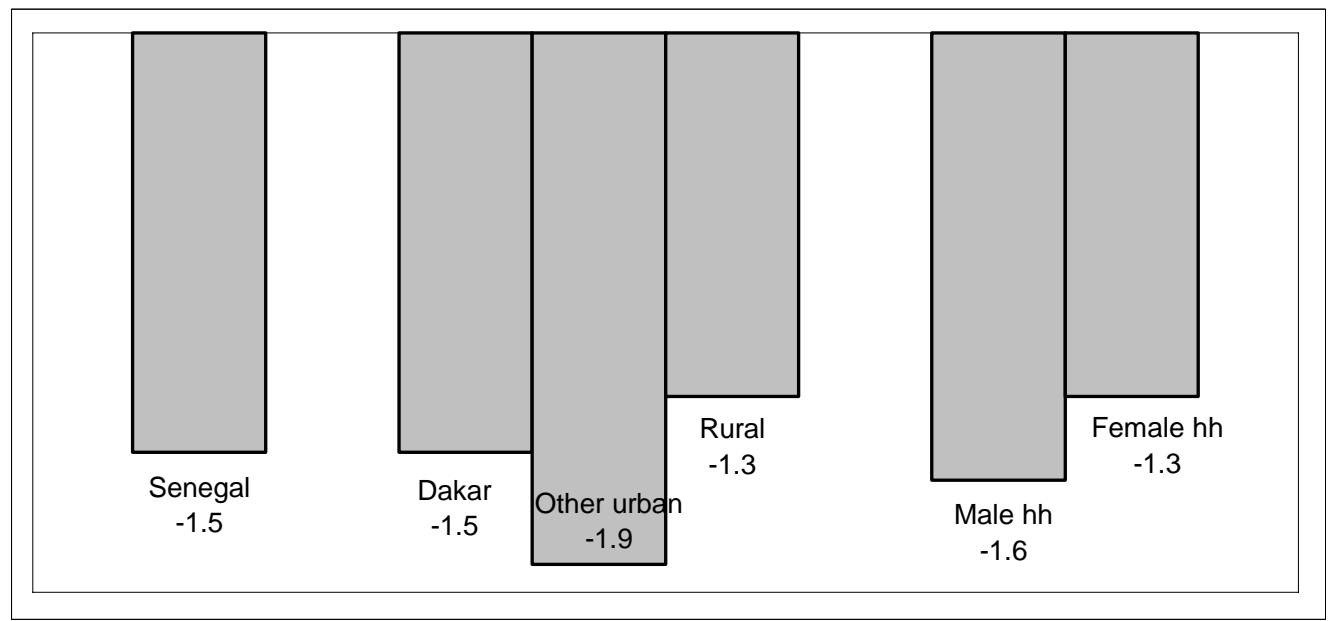

Note: $\mathrm{hh}=$ headed-household

Given that the sectors with the highest initial levels of tariff protection are primarily industrial, in particular the agricultural-based industries (meat products, grain products, food processing, beverages, tobacco and leather) and oil refining. It is naturally in these sectors that import prices fall most and import volumes increase most (Table 3). In contrast, the service sectors, most agricultural sectors and several of the industrial sectors are subject to low or moderate import tariffs and thus have a small or even negative import response . The 2 percent compensatory sales tax slightly offsets the fall in primary and industrial import prices, while leading to a small increase in the import prices of importable services.

Overall, our simulation indicates that the elimination of import tariffs would lead to a 2.4 percent increase in output and a 2.1 percent increase in GDP (value added) immediately in the first year 
(Table 3). As we will discuss in more detail later in the document, this result is almost entirely driven by the productivity/efficiency gains from increased openness, as we assume that any increase in capital stock in the first year only becomes productive in the second year.

The sectoral distribution of this output effect depends not only on the initial tariff rates and import response, but also on the degree of exposure of each sector to import competition and their capacity to capitalize on the emerging export opportunities. Indeed, the sectors posting the most substantial output growth following trade liberalization (Table 3) - hospitality, meat products, other services, chemical products, tobacco, and fishery - are characterized by high export orientation (Annex 1; export/output ratio) and, generally, low import competition (Annex 1 ; import/consumption ratio). In contrast, the main contracting sectors - transport material, machinery, paper products and grain products - all face moderate to high initial tariff protection, substantial import competition and limited export markets ${ }^{25}$.

The output effects in the agricultural (subsistence agriculture, cash crops and livestock) and forestry sectors are quite striking and feature a strong factor price effect. Given moderately high initial tariff rates, tariff cuts lead to substantial import competition, particularly in the subsistence agriculture sector which features an initial 21.4 percent import penetration rate. At the same time, there are very limited export opportunities for these sectors, as reflected in their low export ratios. As their principal factors of production - rural male and female labor - are little employed in other sectors ${ }^{26}$, they are essentially "captive" and their wages fall precipitously (Table 4). This translates into strong reductions in output prices yet, with the exception of the livestock sector, little change in output volumes (Table 3).

The service sectors are characterized by zero initial tariff rates, low import competition and limited export opportunities, with the exception of the export-oriented tourism and "other services" sectors. As a result, the main impact of tariff cuts is a reduction in input costs, which translate into small to moderate output expansions and small output price reductions (Table 3).

This dichotomy between the evolution of output prices in the services and non-services (primary and industrial) sectors is accentuated when we take account of changes in input costs as reflected in value added prices (Table 3). As all sectors use a mix of inputs coming from various sectors, the variations in sectoral input costs tend to be intermediary relative to the sectoral output prices. In the industrial and agricultural sectors where output prices fall most, input prices fall less than proportionately, such that the burden of adjustment falls on factor prices as revealed by the larger reductions in value added prices. This is particularly dramatic for a large number of industrial sectors, where the drop in value added prices is often more than twice the drop in output prices even if, on average, the gap is larger in the primary sector. The converse is true for the mainly service sectors for which output prices fall little and input costs fall proportionately more. For these sectors value added prices tend to fall less than output prices.

\footnotetext{
${ }^{25}$ Note that the average increase in the volume of output is not equal to the average increase in the volume of value added due to due to the fact that in averaging we are using different sub sectoral weight for output and value added.

${ }^{26}$ Indeed, 84 percent of rural female labor income is employed by these four sectors (Table 4).
} 
In conclusion, as would be expected, trade liberalization leads to a reallocation of resources in favor of the export-oriented sectors (meat products, chemical, rubber and leather products, etc.) and to the detriment of their import-competing counterparts (transport material, machinery, paper product, textiles etc.). As there is a similar mix of these two types of sectors in both the primary and industrial sectors, there is no major difference in their aggregate results. The primary and services sector expand slightly more than the industrial sector. However, value added prices in the agricultural sector fall 25 percent more than in the industrial sector and three times more than in the services sector. It is this divergence in the behavior of value added prices that drives the impacts on factor prices, as we will now explore.

Let us now look more generally at how the sectoral output effects of trade liberalization map into the evolution of factor prices in the first year. It is important to first note that the overall consumer price index falls by 7.5 percent and thus, although, factor returns fall, they almost all increase in terms of purchasing power.

As we indicated above, rural labor is only used to a very limited extent outside the three main agricultural sectors (subsistence agriculture, cash crop, livestock). Thus, the considerable reduction in agricultural value added prices discussed above translates into a substantial reduction in the wages of rural workers (second-last line of Table 3). In contrast, urban workers have more scope to migrate from the contracting import-competing sectors to the expanding export-oriented and service sectors, such that their wage rates fall much less. Among urban workers, skilled wages fall less than unskilled wages, as skilled workers are employed proportionately more in the (expanding) service sectors.

If we now turn our attention to the gender impacts, we first note that the increase in the skill gap is more pronounced among urban female workers, as unskilled wages fall more and skilled wages fall less relative to their male counterparts (Table 4). As a result, the gender gap increases among unskilled workers, whereas it diminishes among skilled workers. In rural areas, the gender gap also widens slightly as female workers, who derive 51 percent of their income from the agricultural sectors, have a short-term wage drop of 5.3 percent, as compared to 5.2 percent for their male counterparts (Table 4; second-last row). Thus the gender wage gap increases marginally among the poorest population groups - rural workers and urban unskilled workers and declines among the less-poor urban skilled workers. Overall, the gender wage gap increases, albeit marginally, as average wages for female workers (urban and rural together) fall by 4.1 percent, as compared to 4 percent for male workers (Table 4). Thus trade liberalization is shown to slightly accentuate both existing gender and skill wage gaps in Senegal by favoring sectors that are relatively more intensive in male labor.

Sectoral returns to capital generally reflect changes in sectoral value added prices and thus fall the most in the import-competing sectors (beverages, grain products, transport material, paper products, leather, other manufacturing, machinery, food processing, etc.), where capital intensity is greatest (Table 3). Relative to the consumer price index, rates of returns to capital increase for many, primarily export-oriented and service, sectors. 
Table 3: Sectoral responses

\begin{tabular}{|c|c|c|c|c|c|c|c|c|c|c|c|c|c|c|c|c|c|c|}
\hline & \multicolumn{8}{|c|}{ PRICES } & \multicolumn{10}{|c|}{ VOLUMES } \\
\hline & \multicolumn{4}{|c|}{ First year } & \multicolumn{4}{|c|}{ Last year } & \multicolumn{5}{|c|}{ First year } & \multicolumn{5}{|c|}{ Last year } \\
\hline & Imports & $\begin{array}{c}\text { Dom. } \\
\text { sales }\end{array}$ & Output & $\begin{array}{r}\text { Value } \\
\text { added }\end{array}$ & Imports & $\begin{array}{c}\text { Dom. } \\
\text { sales }\end{array}$ & Output & $\begin{array}{r}\text { Value } \\
\text { added }\end{array}$ & Imports & $\begin{array}{c}\text { Dom. } \\
\text { sales }\end{array}$ & Exports & Output & $\begin{array}{r}\text { Value } \\
\text { added }\end{array}$ & Imports & $\begin{array}{c}\text { Dom. } \\
\text { sales }\end{array}$ & Exports & Output & $\begin{array}{l}\text { Value } \\
\text { added }\end{array}$ \\
\hline Subsistence & -13.7 & -8.1 & -10.4 & -12.0 & -13.7 & -6.5 & -8.9 & -10.3 & 12.9 & -0.3 & 24.8 & 0.1 & 0.1 & 16.6 & -0.5 & 20.2 & -0.1 & -0.1 \\
\hline Cash crops & -10.1 & -7.7 & -8.6 & -9.7 & -10.1 & -6.0 & -6.9 & -7.7 & 5.9 & 0.6 & 21.2 & 1.2 & 1.2 & 9.5 & 0.2 & 16.2 & 0.7 & 0.7 \\
\hline Livestock & -10.2 & -11.2 & -12.9 & -14.8 & -10.2 & -7.0 & -8.8 & -9.7 & 2.4 & 4.7 & 38.3 & 5.0 & 5.0 & 13.3 & 5.5 & 27.0 & 5.7 & 5.7 \\
\hline Forestry & -8.9 & -6.9 & -8.2 & -11.3 & -8.9 & -4.7 & -6.1 & -8.2 & 5.6 & 1.2 & 20.7 & 1.6 & 1.6 & 10.2 & 0.8 & 14.7 & 1.1 & 1.1 \\
\hline Fishery & 0.7 & -0.4 & -1.7 & 0.6 & 0.7 & -4.1 & -3.8 & -4.6 & 0.4 & 2.6 & 7.9 & 4.3 & 4.3 & -3.1 & 6.9 & 21.2 & 12.1 & 12.1 \\
\hline Mining & -0.3 & -0.1 & -1.5 & 0.2 & -0.3 & -0.5 & -1.8 & -1.1 & 2.3 & 1.8 & 6.0 & 2.8 & 2.8 & 5.4 & 5.8 & 11.0 & 7.1 & 7.1 \\
\hline PRIMARY & -4.8 & -7.1 & -8.3 & -10.0 & -4.4 & -5.5 & -6.7 & -8.1 & 5.4 & 1.8 & 9.6 & 2.5 & 2.3 & 8.4 & 2.6 & 18.1 & 4.3 & 3.6 \\
\hline Meat products & -15.4 & -6.6 & -6.0 & -7.0 & -15.4 & -6.9 & -5.7 & -7.4 & 24.4 & 2.0 & 21.8 & 7.6 & 7.6 & 26.9 & 4.8 & 26.0 & 12.2 & 12.2 \\
\hline Grain products & -17.0 & -8.9 & -10.7 & -18.5 & -17.0 & -7.2 & -9.0 & -12.8 & 19.8 & -0.6 & 25.0 & -0.3 & -0.3 & 24.0 & -0.9 & 19.9 & -0.7 & -0.7 \\
\hline Food processing & -17.5 & -9.0 & -9.2 & -16.0 & -17.5 & -7.2 & -7.6 & -11.3 & 17.5 & -3.5 & 21.6 & 0.2 & 0.2 & 21.0 & -4.4 & 15.7 & -1.2 & -1.2 \\
\hline Beverages & -17.7 & -7.5 & -9.2 & -21.1 & -17.7 & -5.6 & -7.4 & -14.5 & 25.6 & -0.6 & 21.2 & -0.2 & -0.2 & 30.9 & -0.5 & 16.5 & -0.2 & -0.2 \\
\hline Tobacco & -16.0 & -5.5 & -6.2 & -12.0 & -16.0 & -4.0 & -4.8 & -6.6 & 29.3 & 2.2 & 19.4 & 5.0 & 5.0 & 34.9 & 3.2 & 16.7 & 5.8 & 5.8 \\
\hline Textiles & -12.6 & -5.3 & -6.4 & -12.2 & -12.6 & -3.7 & -5.0 & -9.0 & 15.4 & -1.8 & 14.2 & 0.0 & 0.0 & 19.9 & -1.3 & 10.9 & 0.2 & 0.2 \\
\hline Leather & -18.6 & -11.4 & -11.6 & -21.1 & -18.6 & -7.7 & -8.4 & -14.4 & 20.4 & 1.6 & 34.9 & 5.4 & 5.4 & 26.4 & -1.8 & 20.3 & 1.0 & 1.0 \\
\hline Wood products & -11.2 & -7.0 & -8.5 & -11.1 & -11.2 & -5.1 & -6.8 & -8.9 & 11.3 & 1.5 & 22.4 & 2.4 & 2.4 & 14.8 & 0.7 & 16.8 & 1.4 & 1.4 \\
\hline Paper products & -11.0 & -6.8 & -8.7 & -16.9 & -11.0 & -4.3 & -6.2 & -10.2 & 8.3 & -1.2 & 0.0 & -1.2 & -1.2 & 13.7 & -1.7 & 0.0 & -1.7 & -1.7 \\
\hline Petroleum products & -21.3 & -1.8 & -2.0 & -8.7 & -21.3 & -1.3 & -1.7 & -4.4 & 53.1 & -1.5 & 6.0 & 1.7 & 1.7 & 58.8 & 1.1 & 7.6 & 4.0 & 4.0 \\
\hline Chemical products & -8.9 & -2.0 & -2.4 & 1.4 & -8.9 & -3.5 & -2.6 & 0.3 & 11.4 & -3.8 & 12.8 & 7.5 & 7.5 & 19.9 & 6.7 & 29.1 & 22.6 & 22.6 \\
\hline Rubber products & -11.5 & -7.5 & -7.3 & -8.1 & -11.5 & -6.8 & -6.6 & -6.9 & 8.0 & -1.1 & 20.5 & 3.6 & 3.6 & 10.9 & 0.1 & 20.2 & 4.9 & 4.9 \\
\hline Glass products & -11.0 & -7.3 & -7.4 & -13.9 & -11.1 & -5.2 & -5.6 & -8.8 & 7.6 & -0.9 & 19.4 & 2.3 & 2.3 & 11.2 & -2.1 & 12.6 & 0.3 & 0.3 \\
\hline Metal products & -8.9 & -5.3 & -5.5 & -5.2 & -8.9 & -5.1 & -5.4 & -5.2 & 5.3 & -2.6 & 14.9 & 2.6 & 2.6 & 7.3 & -1.1 & 16.2 & 4.1 & 4.1 \\
\hline Machinery & -10.2 & -6.1 & -8.1 & -15.1 & -10.2 & -4.5 & -6.6 & -9.2 & 7.3 & -1.8 & 0.0 & -1.8 & -1.8 & 8.9 & -3.6 & 0.0 & -3.6 & -3.6 \\
\hline Transport material & -12.2 & -6.4 & -8.4 & -16.6 & -12.2 & -4.5 & -6.5 & -11.5 & 10.8 & -2.5 & 0.0 & -2.5 & -2.5 & 12.3 & -5.1 & 0.0 & -5.1 & -5.1 \\
\hline Other manufacturing & -15.3 & -10.6 & -11.7 & -18.8 & -15.3 & -6.5 & -7.9 & -12.1 & 13.3 & 1.7 & 32.6 & 3.3 & 3.3 & 22.5 & 0.6 & 19.9 & 1.6 & 1.6 \\
\hline Utilities & 0.0 & -1.1 & -3.2 & -1.7 & 0.0 & -0.9 & -2.9 & -2.3 & 0.0 & 0.8 & 0.0 & 0.8 & 0.8 & 0.0 & 2.9 & 0.0 & 2.9 & 2.9 \\
\hline Construction & 0.0 & -2.0 & -4.2 & -2.2 & 0.0 & -1.7 & -3.9 & -2.4 & 0.0 & 1.9 & 0.0 & 1.9 & 1.9 & 0.0 & 2.2 & 0.0 & 2.2 & 2.2 \\
\hline INDUSTRIAL & -13.2 & -5.3 & -6.1 & -7.9 & -13.0 & -4.1 & -5.1 & -6.0 & 13.2 & 0.0 & 13.8 & 2.3 & 3.0 & 16.3 & 0.5 & 19.8 & 4.2 & 5.5 \\
\hline Trade & 0.0 & -2.6 & -4.6 & -3.2 & 0.0 & -1.4 & -3.5 & -1.6 & 0.0 & 1.5 & 0.0 & 1.5 & 1.5 & 0.0 & 3.6 & 0.0 & 3.6 & 3.6 \\
\hline Hospitality & 0.0 & -16.0 & -5.2 & 3.0 & 0.0 & -20.3 & -5.5 & -1.2 & 0.0 & 8.2 & 14.7 & 12.8 & 12.8 & 0.0 & 13.4 & 22.2 & 20.1 & 20.1 \\
\hline Transport & 1.7 & -1.6 & -3.1 & -3.0 & 1.7 & -1.1 & -2.6 & -2.6 & -4.6 & 1.8 & 9.5 & 2.9 & 2.9 & -1.9 & 3.8 & 10.6 & 4.9 & 4.9 \\
\hline Telecommunications & 2.0 & -3.3 & -4.5 & -5.4 & 2.0 & -1.8 & -3.1 & -3.7 & -8.3 & 1.9 & 13.5 & 3.6 & 3.6 & -4.3 & 3.2 & 11.6 & 4.7 & 4.7 \\
\hline Finances & 1.8 & 1.4 & -0.6 & 0.1 & 1.8 & 1.0 & -0.9 & -0.7 & 1.0 & 1.9 & 3.3 & 2.1 & 2.1 & 2.1 & 3.7 & 5.9 & 4.0 & 4.0 \\
\hline Real estate & 0.0 & -0.4 & -2.4 & -2.4 & 0.0 & -0.9 & -2.9 & -3.2 & 0.0 & 0.1 & 0.0 & 0.1 & 0.1 & 0.0 & 2.2 & 0.0 & 2.2 & 2.2 \\
\hline Public administration & 0.0 & -2.1 & -4.3 & -4.3 & 0.0 & -0.1 & -2.3 & -1.8 & 0.0 & 0.0 & 0.0 & 0.0 & 0.0 & 0.0 & 0.0 & 0.0 & 0.0 & 0.0 \\
\hline Education & 1.5 & -0.6 & -2.7 & -2.1 & 1.5 & 0.9 & -1.2 & -0.5 & -5.2 & -1.1 & 4.5 & -1.1 & -1.1 & -1.2 & 0.0 & 2.4 & 0.0 & 0.0 \\
\hline Health & 1.5 & -2.3 & -4.3 & -3.6 & 1.5 & -0.6 & -2.6 & -1.4 & -7.4 & 0.0 & 9.2 & 0.0 & 0.0 & -3.2 & 0.9 & 6.4 & 0.9 & 0.9 \\
\hline Other services & 1.5 & -6.8 & -6.8 & -9.9 & 1.5 & -4.9 & -4.7 & -6.8 & -13.1 & 3.1 & 23.8 & 7.5 & 7.5 & -8.8 & 3.9 & 19.7 & 8.8 & 8.8 \\
\hline SERVICES & 1.8 & -1.9 & -3.5 & -3.2 & 1.8 & -1.1 & -2.7 & -2.1 & -1.8 & 1.2 & 12.3 & 2.5 & 1.7 & 0.3 & 2.8 & 15.4 & 4.4 & 3.4 \\
\hline TOTAL & -10.5 & -4.1 & -5.3 & -5.5 & -10.3 & -3.1 & -4.3 & -4.1 & 10.7 & 0.8 & 13.2 & 2.4 & 2.1 & 13.7 & 1.8 & 18.2 & 4.3 & 3.9 \\
\hline
\end{tabular}


Households face a 4 percent first-year reduction in (nominal) income, but experience a smaller 2 percent income fall by the final year (Table 5). This result can be understood by examining the second last column of Table 5, which decomposes the total first-year variation in household income by source. The reduction in income is primarily attributable to the fall in non-factor income, which consists of transfers received from other households (e.g. domestic remittances) and from government (e.g. public assistance). Indeed, these transfers are indexed to the consumer price index, which falls by 7.5 percent in the short term ${ }^{27}$. Capital income represents a similarly large share of total income, although its impact on total income is smaller as its rate of return falls less. Senegalese households also rely more on urban wages than rural wages, which fall more. The contribution of male wage is more than double that of female wage income (28.4 vs. 12.5$)^{28}$.

The principal direct benefit of trade liberalization for households is the reduction in consumer prices by 7.5 percent. In this case, consumer prices fall much more than nominal incomes of households, engendering a considerable rise in purchasing power or real income. Thus, households gain through a combination of moderate nominal income losses and strong consumer price savings, which translates into higher real income of 3.8 and 5 percent in the $1^{\text {st }}$ and $15^{\text {th }}$ year respectively.

\section{b. Long-run effects}

The study integrates the growth processes set in motion by trade liberalization. We noted above that trade liberalization increases the real rate of return to capital which, in our model, stimulates household and foreign savings. In addition, increased openness generates sector-specific productivity and efficiency gains, which further encourages domestic investment and growth. Finally, trade liberalization reduces the prices of capital goods, thus increasing the real investments attainable for a given level of savings.

In the absence of trade liberalization, our model is in a steady state, defined as a state where all volumes and values increases at the same rate - equal to the population growth rate - and relative prices remain constant. This rate is given by the rate of increase in the population, which we set equal to four percent per year and apply to all labor categories. All results are expressed as a variation with respect to the values observed in the "business-as-usual" scenario with no trade liberalization.

${ }^{27}$ Other non-factor incomes include transfers from abroad (e.g. remittances) and dividends. Transfers from abroad are constant, as they are indexed to the exchange rate, which is the model numeraire. Dividends are a fixed share of firm income, which essentially follows the variation in the average returns to capital.

${ }^{28}$ From table 4: Income from male labor $(12.1+7+9.3=28.4)$; Income from female labor $(4.5+2.3+5.7=12.5)$ 
Table 4: Factor Price Effects

\begin{tabular}{|c|c|c|c|c|c|c|c|c|c|c|c|}
\hline & \multicolumn{2}{|c|}{$\begin{array}{c}\text { Value added } \\
\text { price }\end{array}$} & \multicolumn{3}{|c|}{ Male } & \multicolumn{3}{|c|}{ Female } & & \multicolumn{2}{|c|}{$\begin{array}{c}\text { Returns to } \\
\text { capital }\end{array}$} \\
\hline & $\begin{array}{l}\text { First } \\
\text { year }\end{array}$ & $\begin{array}{l}\text { Last } \\
\text { year }\end{array}$ & Rural & $\begin{array}{l}\text { Urban } \\
\text { skilled }\end{array}$ & $\begin{array}{r}\text { Urban } \\
\text { unskilled }\end{array}$ & Rural & $\begin{array}{l}\text { Urban } \\
\text { skilled }\end{array}$ & $\begin{array}{r}\text { Urban } \\
\text { unskilled }\end{array}$ & Capital & $\begin{array}{l}\text { First } \\
\text { year }\end{array}$ & $\begin{array}{l}\text { Last } \\
\text { year }\end{array}$ \\
\hline & \multicolumn{9}{|c|}{ SECTORAL SHARES IN FACTOR PAYMENTS } & & \\
\hline Subsistence & -12.0 & -10.3 & 22.3 & 1.3 & 1.5 & 23.4 & 1.4 & 1.8 & 2.8 & -9.6 & -5.1 \\
\hline Cash crops & -9.7 & $7 \quad-7.7$ & 9.9 & 0.6 & 0.6 & 10.3 & 0.6 & 0.8 & 1.9 & -7.5 & -4.3 \\
\hline Livestock & -14.8 & $\begin{array}{ll}3 & -9.7\end{array}$ & 14.7 & 0.9 & 1.0 & 15.4 & 0.9 & 1.2 & 3.1 & -8.8 & -3.1 \\
\hline Forestry & -11.3 & -8.2 & .9 & 0.1 & 0.1 & 0.9 & 0.1 & 0.1 & 1.3 & -9.2 & -4.2 \\
\hline Fishery & 0.6 & -4.6 & 0.9 & 0.7 & 1.2 & 1.0 & 0.9 & .9 & 2.9 & 3.6 & -1.9 \\
\hline Mining & 0.2 & -1.1 & 1.1 & 2.0 & 0.9 & 0.3 & 0.8 & 0.6 & 1.6 & 2.1 & -2.3 \\
\hline PRIMARY & -10.0 & -8.1 & 49.7 & 5.5 & 5.2 & 51.4 & 4.8 & 5.3 & 13.5 & -4.9 & -3.4 \\
\hline Meat $\mathrm{F}$ & -7.0 & -7.4 & 0.7 & 1.6 & 2.1 & 0.7 & $1.3^{3}$ & 1.2 & 5.6 & -0.4 & -2.1 \\
\hline Grain products & -18.5 & -12.8 & 0.8 & 1.9 & 2.5 & 0.8 & 1.6 & 1.4 & 1.0 & -17.5 & -5.3 \\
\hline Food processing & -16.0 & -11.3 & 0.9 & 2.1 & 2.8 & 0.9 & 1.8 & 1.6 & 1.0 & -14.8 & -5.3 \\
\hline Beverages & -21.1 & -14.5 & 0.1 & 0.3 & 0.4 & 0.1 & 0.2 & 0.2 & 0.1 & -19.7 & -5.3 \\
\hline Tobacco & -12.0 & -6.6 & 0.1 & 0.2 & 0.2 & 0.1 & 0.1 & 0.1 & 0.2 & -7.4 & -2.7 \\
\hline Textiles & -12.2 & -9.0 & 1.7 & 2.4 & 5.3 & 1.8 & 0.9 & 9 & 0.7 & -11.8 & -5.0 \\
\hline Lea & -21.1 & $\mid-14.4$ & 0.0 & & 0.1 & 0 & & 1 & 0.3 & -16.0 & -5.3 \\
\hline Voc & -11.1 & -8.9 & 0 & & 1.3 & 0 & & .7 & 0.6 & -8.3 & -4.6 \\
\hline Papes & -16.9 & -10.2 & 0. & 0 & 0.8 & 0. & 0. & 0.4 & 0.8 & -16.1 & -4.5 \\
\hline Petrole & -8.7 & $7 \quad-4.4$ & 0.2 & 0.2 & 0.5 & 0.2 & 0.1 & 0.3 & 0.6 & -6.8 & -2.6 \\
\hline Chen & 1.4 & 0.3 & 0.9 & 1 & 2.7 & 0.9 & 0.5 & 1.5 & 3.0 & 6.7 & 1.9 \\
\hline Rubbe & -8.1 & -6.9 & 0.1 & 0.1 & 0.2 & 0.1 & 0.0 & 0.1 & 0.7 & -4.8 & -3.3 \\
\hline Glass F & -13.9 & -8.8 & 0.2 & 0.3 & 0.7 & 0.2 & 0.1 & 0.4 & 1.4 & -11.2 & -4.4 \\
\hline Metal products & -5.2 & -5.2 & 0.2 & 0.3 & 0.6 & 0.2 & 0.1 & 0.3 & 1.2 & -3.0 & -3.5 \\
\hline $\mathrm{Ma}$ & 5.1 & -9.2 & 0 & & 0.2 & 0 & & 1 & 0.1 & -14.8 & -5.0 \\
\hline Tra & -16.6 & -11.5 & 0 & & 0.1 & 0 & & 1 & 0.1 & -16.3 & -6.2 \\
\hline ufacturing & -18.8 & $3-12.1$ & 0 & & 0.9 & 0. & 0 & 0.5 & 2.0 & -15.1 & -4.3 \\
\hline Utiliti & -1.7 & $\begin{array}{ll}7 & -2.3\end{array}$ & 0. & 2 & 1.5 & $0 .(1-x-x)$ & 0.2 & 1.8 & 3.4 & -1.2 & -3.0 \\
\hline Cons & -2.2 & -2.4 & 3.1 & 4.3 & 6.3 & 2.8 & 2.4 & 4.6 & 5.3 & -1.1 & -3.5 \\
\hline INDUSTRIAL & -7.9 & -6.0 & 10.3 & 18.6 & 29.2 & 9.9 & 10.1 & 18.3 & 28.1 & -4.3 & -2.9 \\
\hline Trade & -3.2 & -1.6 & \begin{tabular}{|l|}
3.2 \\
\end{tabular} & 19.1 & 27.6 & 20.2 & 17.9 & 27.2 & 17.8 & -2.6 & -2.5 \\
\hline Hospitality & 3.0 & -1.2 & 0.9 & 1.6 & 1.8 & 0.3 & 3.5 & 0.6 & 0.8 & 13.9 & -1.2 \\
\hline Transport & -3.0 & -2.6 & 3.2 & 8 & 6.7 & 1.7 & 3.8 & 3.1 & 4.3 & -1.1 & -2.7 \\
\hline Telecommunications & -5.4 & -3.7 & 4.5 & 5.2 & 9.3 & 2.4 & 5.2 & 4.3 & 5.7 & -2.7 & -2.8 \\
\hline Financ & 0.1 & -0.7 & 1.3 & 23.5 & 2.3 & 2.4 & 25.8 & 2.9 & 5.8 & 3.0 & -3.6 \\
\hline Rea & -2.4 & -3.2 & 0 & & 0.4 & 0. & 1. & 0.4 & 11.7 & -2.3 & -3.3 \\
\hline ministration & -4.3 & $3-1.8$ & 8.3 & 10.9 & 8.7 & 5.7 & 14.0 & 18.9 & 6.6 & -4.8 & -3.6 \\
\hline Education & -2.1 & -0.5 & 6.1 & & 6.4 & 4.2 & 10.2 & 13.7 & 1.3 & -4.7 & -4.1 \\
\hline Health & -3.6 & -1.4 & 1.9 & 2.5 & 2.0 & 1.3 & 3.2 & 4.4 & 1.0 & -4.4 & -3.4 \\
\hline Other services & -9.9 & -6.8 & 0.4 & 0.5 & 0.4 & 0.2 & 0.6 & 0.8 & 3.4 & -3.2 & -2.4 \\
\hline SERVICES & -3.2 & -2.1 & 40.0 & 75.9 & 65.6 & 38.8 & 85.2 & 76.4 & 58.4 & -2.0 & -3.0 \\
\hline TOTAL & -5.5 & ; -4.1 & 100.0 & 100.0 & 100.0 & 100.0 & 100.0 & 100.0 & 100.0 & -3.1 & -3.0 \\
\hline \multicolumn{12}{|c|}{ VARIATIONS IN FACTOR PRICES RELATIVE TO BUSINESS AS USUAL SCENARIO } \\
\hline & & & -5.2 & -2.2 & -3.9 & -5.3 & -2.1 & -4.0 & -3.1 & & \\
\hline Last year & & & -2.3 & 3.9 & -1.2 & -2.4 & 4.1 & -1.4 & -3.0 & & \\
\hline
\end{tabular}


Table 5: Household Income Effects

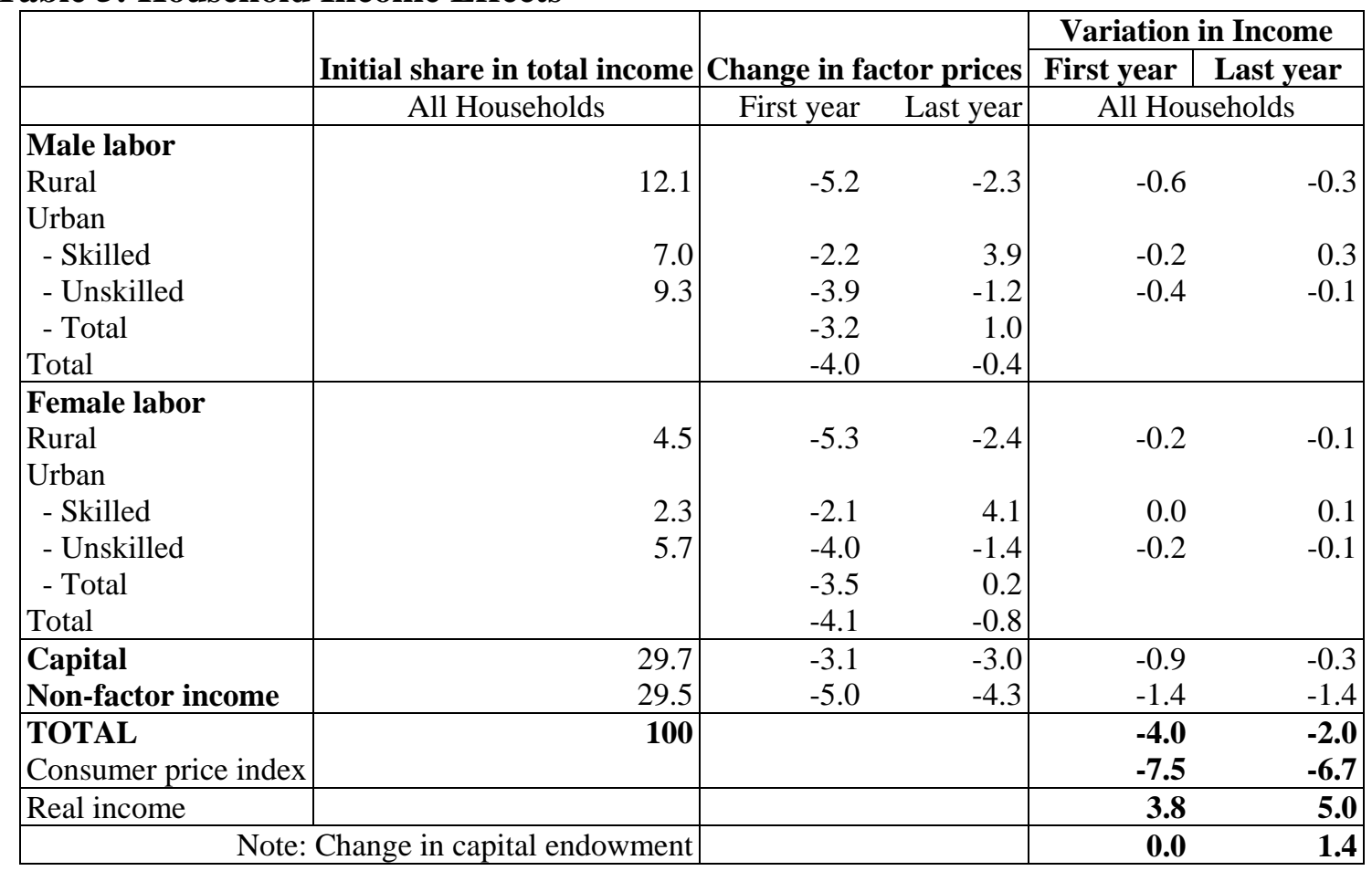

Most of these channels already kick in to a large degree in the first year of the simulations. Indeed, relative to the business-as-usual (BAU) scenario, the real rate of return to capital increases with trade liberalization by 4.8 percent in the first year, whereas at the end of the 15 year simulation, it is only 3.9 percent higher than in the BAU (Table 5). The openness indicator rises by 9.2 percent on average in the first year, but then only climbs a further 1.7 percentage points to attain a 10.9 percent increase relative to BAU after 15 years. Practically all of the reduction in the prices of capital goods also occurs in the first year. As a result, more than half of the increase in GDP relative to the BAU occurs in the first year - 2.1 percent, relative to 3.9 percent after 15 years - the rest of the gains resulting from the cumulative nature of the growth process.

Consequently, the long-term effects are not substantially different from the short-term effects. The essential difference in the long-term effects is the result of three phenomena. First, as we will see in the growth channels analysis below, the productivity/efficient channel is by far the strongest and favors the industrial sector far more than the others. At the same time, the sectoral allocation of investments over time favors the export-oriented sectors where real rates of return to capital shoot up immediately after trade liberalization. This tends to emphasize the sectoral divergence in the output effects, while reducing the divergence in the price effects. While exportoriented sectors are also found in agriculture (fishery and mining), they play a larger role in industry. As a result of these two first phenomena, the long-term increase in value added relative to the BAU is greater for the industrial sector. A third phenomenon is the cumulative growth in the capital stock from the various channels above. Indeed, as we see at the bottom of Table 5 , household capital endowments increase relative to BAU. 
This rise in capital endowments also increases the relative demand for skilled labor (Figure 3), which is complementary to capital in the production process. As a result, skilled wages rise dramatically in the long term. In contrast, rural and unskilled urban real wages increase only moderately. As male workers make up a larger share of skilled workers (notably in agriculture and industry; table 4), the long-term impact is a slight increase in the gender earnings gap.

Figure 3: Real wage rates, differences between long and short run (percentage points)

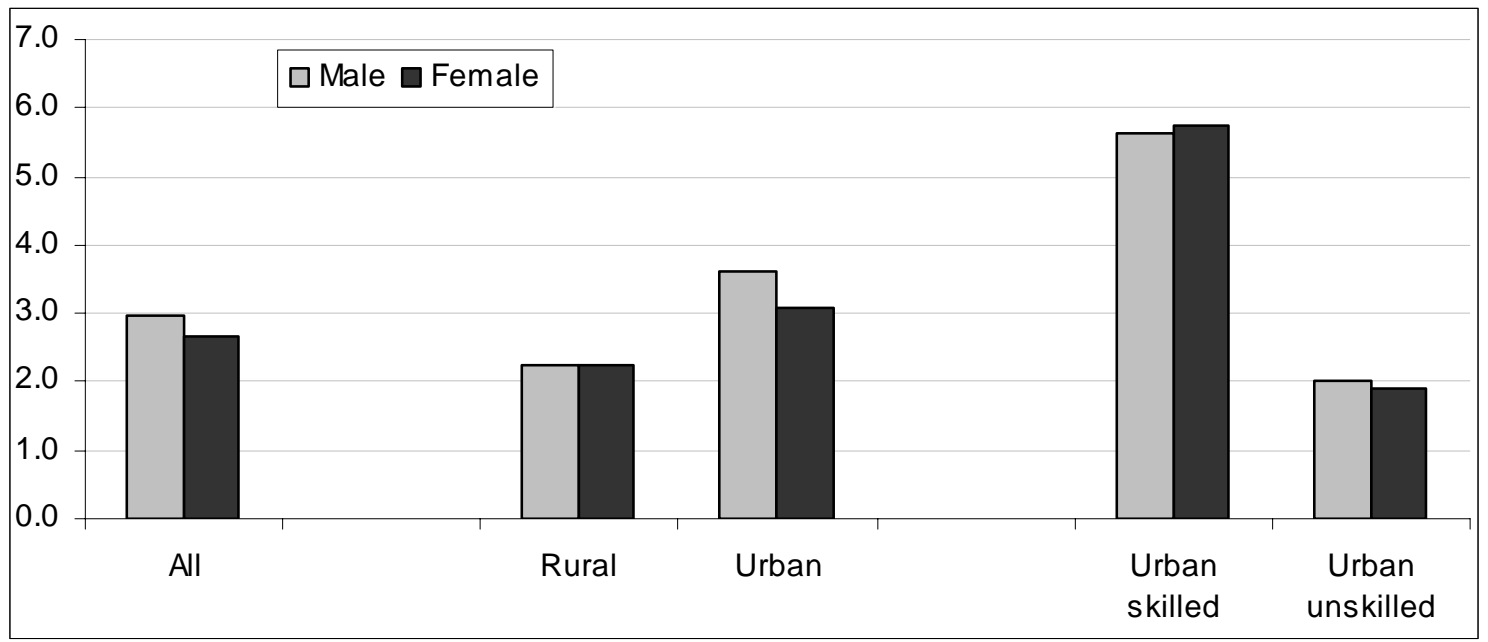

As discussed in the presentation of the model above, we have included a number of motors of growth, which are all intimately linked to trade liberalization. In this section, we separate out their respective impacts on overall growth, the gender wage gap and household incomes. We first note that in our base simulation, in which all motors of growth are included, relative to the BAU trade liberalization increases GDP by a further 2.1 percent in the short run (first year) and by an additional 3.9 percent in the long run (15 years), relative to the simulation without trade liberalization (Table 6). We have already examined the gender-specific labor market effects and the household income effects of the base simulation in the sections above. We now explore each of these channels and their respective impacts on the simulation results. For each simulation we compare the results without one of the growth channels to those obtained in the "Full" scenario, which includes all channels.

\section{- Productivity/efficiency gains}

Productivity/efficiency gains ("productivity gains" hereon) emerge as the strongest of our traderelated motors of growth, despite the adoption of a relatively conservative estimate (0.5) of the elasticity of productivity with respect to the variation in sectoral openness ratios. When we remove this channel - i.e. we assume that productivity is not affected by increased openness practically all the growth effects of trade liberalization disappear. Indeed, we observe a marginal 0.1 percent increase in GDP in the first year followed by a small 0.6 percent increase in GDP by year 15 (Table 6).

When we compare the sectoral results including the productivity gains ("Full") with those obtained in their absence ("NoPE"), it is obvious that the more open industrial and agricultural 
sectors benefit most from these gains (Annex 2). Indeed, in the absence of such gains, trade liberalization leads to a decline in value added (volume) relative to BAU in the agricultural sector in both the short and long terms. Only the limited remaining capital accumulation effects allow the industrial sector to post a moderate 1.9 percent value added gain with respect to BAU in the long run, despite a short-run contraction.

In order to understand the impacts on factor prices, we need to turn our attention to the evolution of value added prices in the presence of productivity gains ("Full"), as presented in Annex 2. We first note that the more open sectors transform these gains into larger price cuts, which is precisely what stimulates their expansion, as compared to the situation where these gains are absent ("NoPE"). At the same time, the productivity gains lead to an increase in incomes, raising demand for all goods. This tempers the reduction in prices in the open sectors and leads to smaller reductions (relative to "NoPE") in prices in the other, particularly service, sectors. This latter effect is sufficient to ensure that factor prices decline less in the presence of productivity gains (Annex 3). The difference is particularly strong in the case of skilled and urban workers, who are employed intensively in the service sector. Although marginal, the productivity/efficiency gains is found to increase the gender wage gap in the long-run (Annex 3), as male workers represent a larger share of skilled workers.

\section{- Foreign investment}

In this simulation, we assume that the current account balance is a fixed share of GDP and reacts neither to the increase the average returns to capital following trade liberalization, nor to the increased level of openness. The results are practically unchanged with respect to the full scenario, which includes these reactions. GDP rises slightly less with respect to BAU in the absence of this channel - 3.4 percent vs. 3.9 percent - by year 15 (Table 6). This is primarily due to a larger long-term increase in industrial output, given that this capital-intensive sector benefits most from the increased foreign investment, on one hand, and the ensuing demand for investment goods, on the other (Annex 2).

Given that male workers are more intensively employed in industrial production, the elimination of the foreign investment growth channel brings their wage rates down more than those of female workers (Annex 3). Thus foreign capital-driven growth shows a clear gender bias in favor of male workers. While these results are not surprising given the estimated elasticities of foreign investment with respect to changes in openness (0.04) and the real returns to capital (0.5), it may be that a more sophisticated modeling of sector-specific foreign investment could have generated stronger results.

\section{- Return-sensitive household savings}

The hypothesis that household savings are sensitive to changes in the average returns to capital has only very moderate impacts on our results. When we remove this channel, the total increase in GDP in the final year falls only by 0.6 percentage points relative to the condition where all growth channels ("Full”) are included (Table 6). In terms of output and value added (Annex 2), it is the capital-intensive industrial sector that benefits most from the increased investment and 
demand for investment goods in the full scenario, relative to the situation without this channel (“NoHS”).

There is an interesting contrast in the evolution of value added prices when we compare the elimination of the foreign savings/investment versus the household savings channel (Annex 2). Whereas the former deepens the first year reduction in agricultural and service prices, the opposite is true when we eliminate the household savings channel. This result can be traced to the reduction in household consumption that occurs when household savings increase in response to a rise in the returns to capital. As households consume relatively more agricultural and service goods than other agents, an increase in their savings further deepens the reduction in the prices of these goods. This mechanism explains why household savings channel is shown to reduce the returns to most factors in the long-run, whereas the contrary is true for the foreign investment channel (Annex 3). Among the urban workers, it is only unskilled workers, who are relatively intensely employed in the industrial sector, have a smaller reduction in their returns (wages) in the presence of the household savings channel. In general terms, the household savings channel is gender-neutral, increasing male and female wages in roughly the same proportion.

\section{- $\quad$ Capital goods price reductions}

Investment in Senegal is composed overwhelmingly of construction goods (71 percent of total consumption for investment), machinery (18 percent) and transport material (9 percent). While trade liberalization has little impact on the price of (non-tradable) construction goods, the prices of machinery and transport material, of which over 90 percent are imported, fall by more than ten percent (Annex 2). As a result, the investment price index declines by roughly five percent, which implies that real investment increases proportionately for a given level of savings available in the economy. In the absence of data on sectoral consumption for investment patterns, we assume that all sectors have the same structure and, consequently, the same investment price index. To examine the specific impact of these investment cost reductions, we run a simulation in which we fix all investment prices at their BAU values (NoPK). As new investment only becomes productive in the following year, this channel has no impact in the first year and we focus instead on the final year impacts.

This channel is shown to be important, as GDP rises almost twice as much by the $15^{\text {th }}$ year when we compare the full simulation (increase of 3.9 percent; Table 6) with the NoPK simulation (increase of 2 percent). Like the household and foreign savings channels, this channel favors the industrial sector both because this sector is capital-intensive - and thus benefits most from capital investments - and because it provides the bulk of investment goods. Indeed, industrial value added increases by 2.6 percentage points in the last year when we compare the full and NoPK simulation results (Annex 2). At the same time, this expansion of the industrial sector leads to a larger reduction in its value added price, which falls by 6 percent as compared to 5.7 percent in NoPK.

The increase in real investments, resulting from capital good price reductions, raises the relative supply of capital. This is shown to play a major role in the fall in the returns to capital in the presence of capital goods price reductions channel, which, in comparison to the NoPK simulation, fall much more than male and female wage rates. Increased real investments also 
dramatically increase the wage rates of skilled male and female workers, which are assumed to be complements to capital. Impacts on rural and unskilled workers are much more modest. As a result of the increase in skilled wages, the gender wage gap increases relative to the simulation with no capital goods price channel (Annex 3).

Table 6: Growth effects

\begin{tabular}{|c|c|c|c|c|c|c|c|c|c|}
\hline & Growth rate & Var & ation il & GDP & elative & o BAU & \multicolumn{3}{|c|}{ Full scenario: Variation in average } \\
\hline Year & BAU & Full & NoPE & NoFS & NoHS & NoPK & $\begin{array}{r}\text { Return to } \\
\text { capital }\end{array}$ & $\begin{array}{r}\text { Openness } \\
\text { ratio }\end{array}$ & $\begin{array}{r}\text { Capital good } \\
\text { price }\end{array}$ \\
\hline 1 & 4.0 & 2.1 & 0.1 & 2.1 & 2.1 & 2.1 & 4.8 & 9.2 & -4.5 \\
\hline 2 & 4.0 & 2.3 & 0.2 & 2.2 & 2.2 & 2.1 & 4.7 & 9.4 & -4.5 \\
\hline 3 & 4.0 & 2.4 & 0.2 & 2.4 & 2.3 & 2.1 & 4.6 & 9.5 & -4.5 \\
\hline 4 & 4.0 & 2.6 & 0.3 & 2.5 & 2.5 & 2.1 & 4.5 & 9.7 & -4.5 \\
\hline 5 & 4.0 & 2.8 & 0.3 & 2.6 & 2.6 & 2.1 & 4.5 & 9.8 & -4.5 \\
\hline 6 & 4.0 & 2.9 & 0.4 & 2.7 & 2.7 & 2.1 & 4.4 & 10.0 & -4.5 \\
\hline 7 & 4.0 & 3.1 & 0.4 & 2.8 & 2.8 & 2.1 & 4.3 & 10.1 & -4.5 \\
\hline 8 & 4.0 & 3.2 & 0.4 & 2.9 & 2.9 & 2.1 & 4.3 & 10.2 & -4.4 \\
\hline 9 & 4.0 & 3.3 & 0.5 & 3.0 & 2.9 & 2.1 & 4.2 & 10.4 & -4.4 \\
\hline 10 & 4.0 & 3.4 & 0.5 & 3.1 & 3.0 & 2.1 & 4.2 & 10.5 & -4.4 \\
\hline 11 & 4.0 & 3.5 & 0.5 & 3.1 & 3.1 & 2.1 & 4.1 & 10.6 & -4.4 \\
\hline 12 & 4.0 & 3.6 & 0.6 & 3.2 & 3.2 & 2.1 & 4.1 & 10.7 & -4.3 \\
\hline 13 & 4.0 & 3.7 & 0.6 & 3.3 & 3.2 & 2.1 & 4.0 & 10.8 & -4.3 \\
\hline 14 & 4.0 & 3.8 & 0.6 & 3.3 & 3.3 & 2.0 & 4.0 & 10.9 & -4.3 \\
\hline 15 & 4.0 & 3.9 & 0.6 & 3.4 & 3.3 & 2.0 & 3.9 & 10.9 & -4.2 \\
\hline
\end{tabular}

Notes: BAU = Business as usual; Full: Core simulation (all growth channels); NoPE = No openness-

productivity/efficiency channel; NoFS = No capital returns/openness-foreign savings channel; NoHS = No capital returns-household savings channel; NoPK = No liberalization-capital good price effect.

\section{- Poverty impacts}

Before examining our poverty indicators, we look more broadly at the distribution of the gains across the whole distribution. Figure 4 depicts the change in the per capita consumption deflated by the household-specific consumer price indices - for each decile. The average percent variation in consumption is computed for the 15 periods in both the BAU and the full trade liberalization scenario. The difference, in percentage points, between these average variations is then calculated for each decile to obtain the growth incidence curve (GIC) in Figure 4. This curve is shown for the $1^{\text {st }}$ and last years of the simulation and on average over the whole simulation period.

The GIC is generally concave indicating that middle income households benefit more. In the first year, the very poorest and the very richest both experience a reduction in consumption relative to BAU, whereas the moderately poor generally benefit less than their richer counterparts. However, the situation of the poorest deciles improves markedly by the $15^{\text {th }}$ year with gain ranging above five percent. The long-term effects are roughly double the short-term effects and tend to favor the lower deciles more. This is due to their greater reliance on labor income in a 
context where wages increase relative to capital and non-factor income in the long-term (see Table 5).

Figure 4: Growth incidence curves for Senegal (consumption)

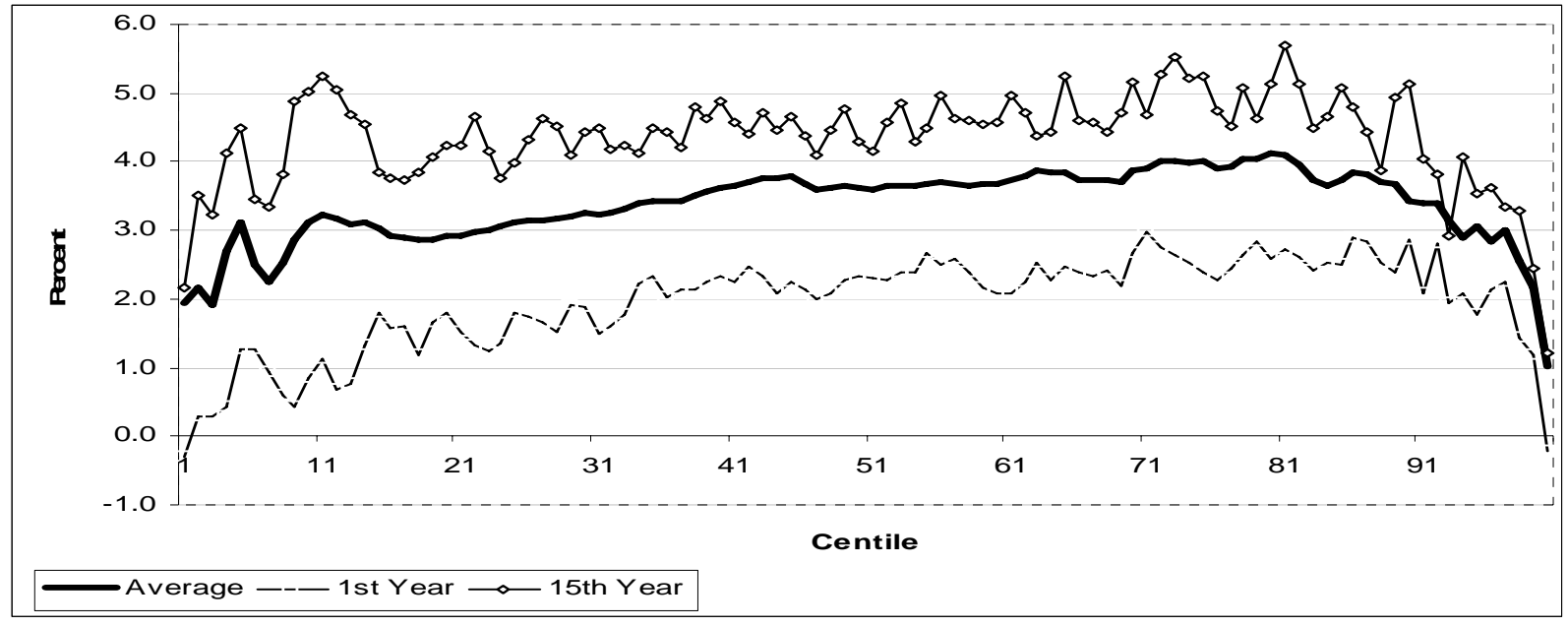

We now focus specifically on the poorest through the analysis of a series of poverty measures. We first note that the incidence of poverty (the headcount index) falls steadily from 53 to 34 percent over the BAU scenario (Figure 5). The simulated elimination of import tariffs (SIM) is shown to reduce the incidence of poverty substantially in the first year from 53 to 50 percent, i.e. a fall of 3 percentage points. This result is in line with our earlier finding that the dynamic gains from trade openness are concentrated, to a large extent, in the first year. Nevertheless the incidence of poverty declines continuously over the rest of the simulation period, finally settling at 2 percentage points lower than the BAU scenario (34 vs. 32 percent).

Figure 5: Change in poverty incidence (percent)

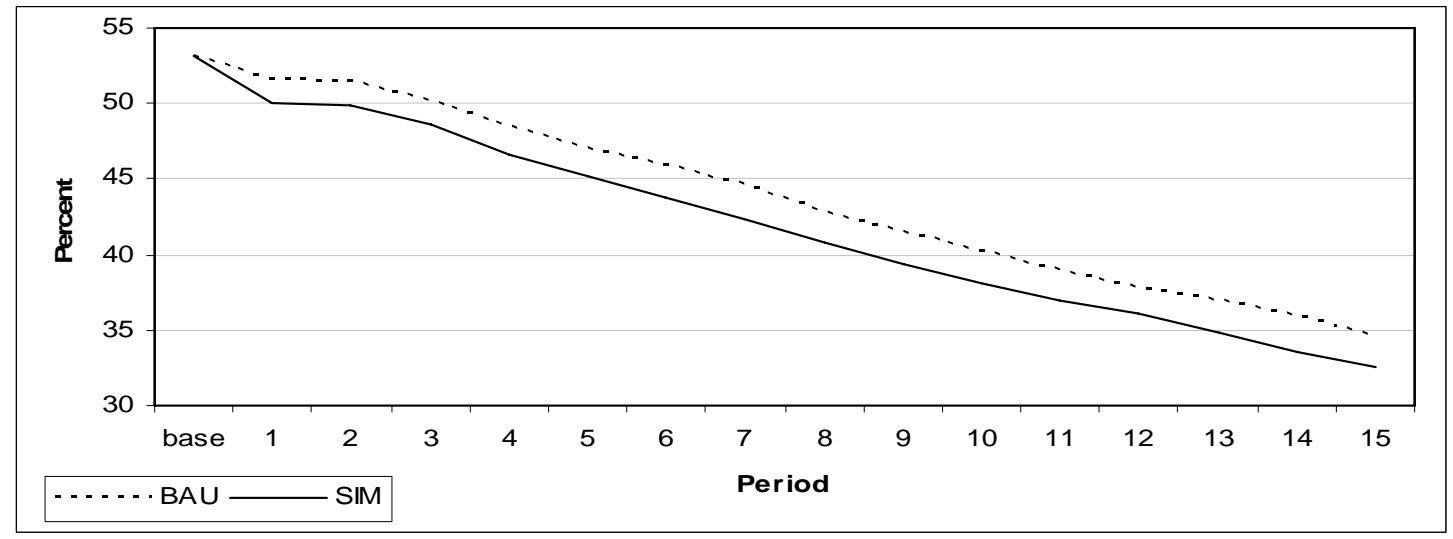


Let us now broaden our analysis to examine changes in the depth and severity of poverty, as measured by the poverty gap and the squared poverty gap, respectively. Figure 6 shows that the percentage reduction in the depth and severity of poverty continue to fall in the long run, but much smaller than the reduction in poverty incidence. This confirms our earlier finding that the poorest deciles gain relatively less compared with the middle income deciles.

\section{Figure 6: Change in poverty incidence, depth and severity (percentage points)}

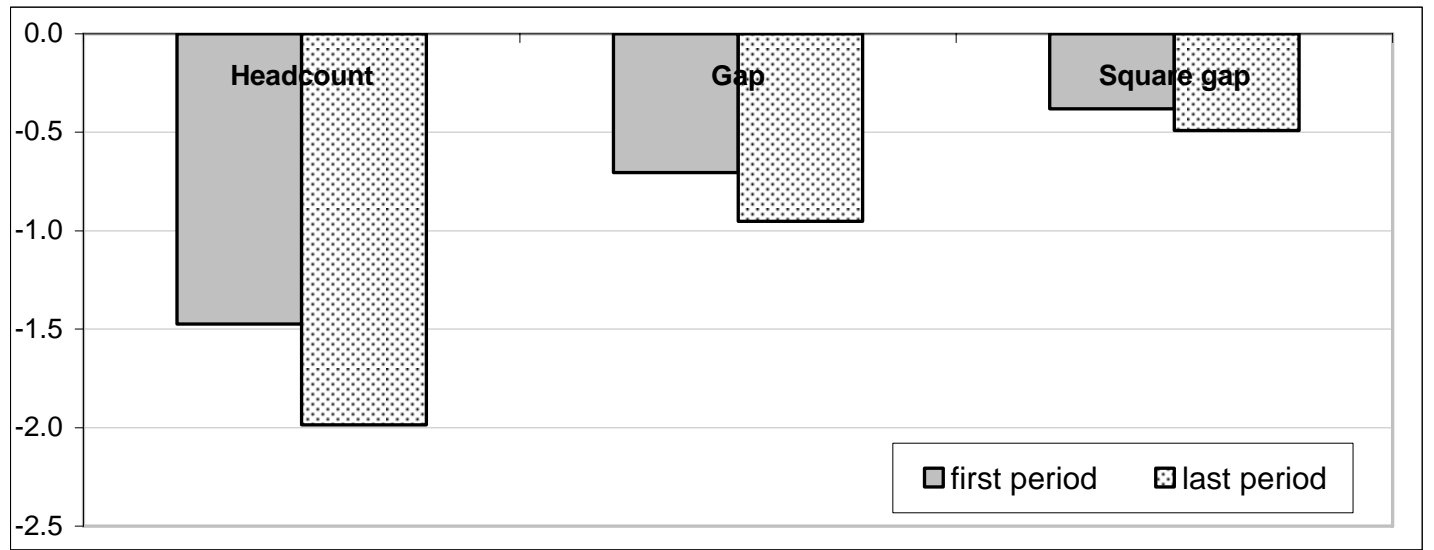

Figure 7 explores poverty impacts by area of residence. The contrast between the short and the long run effects is apparent. If rural households benefit less from the trade liberalization in the short run, they are by far the biggest winners in the long run compared to Dakar and Other urban households. Although poverty drops in the long run in the later areas, the fall is low than what is observed in the first, in particular for the moderate poor households. Thus, poor households benefit relatively more from the removal of import duties in the long run.

These results reflect the interaction between the income and consumer price channels. While rural households experience lower factor returns, they nonetheless benefit more from the ensuing consumer price savings (Table 5). Indeed, rural households consume relatively more agricultural and agro-industrial goods, for which prices fall steeply, whereas urban households, particularly in Dakar, consume more services, for which prices fall only moderately. Variations in the depth (Figure 8) and severity (Figure 9) of poverty are smaller and follow the same trends as poverty incidence in favor of rural areas. Indeed, the reduction in the depth and severity of poverty in the rural areas is at roughly five times greater than in Dakar by the last year. 
Figure 7: Change in poverty incidence by area (percentage points)

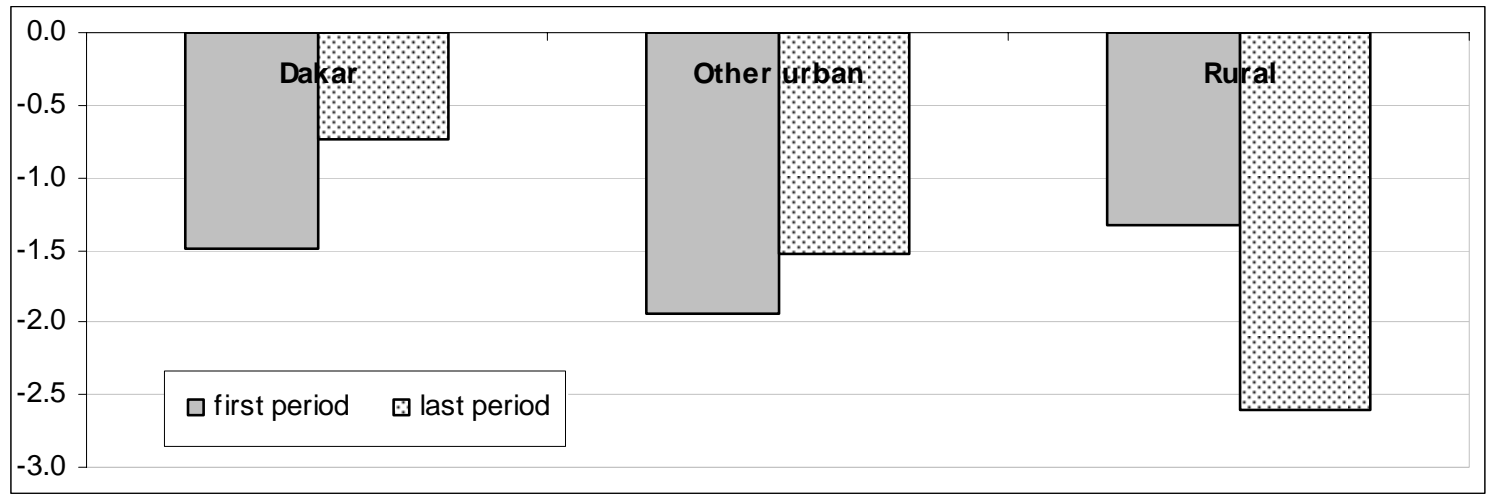

Figure 8: Change in poverty gap by area (percentage points)

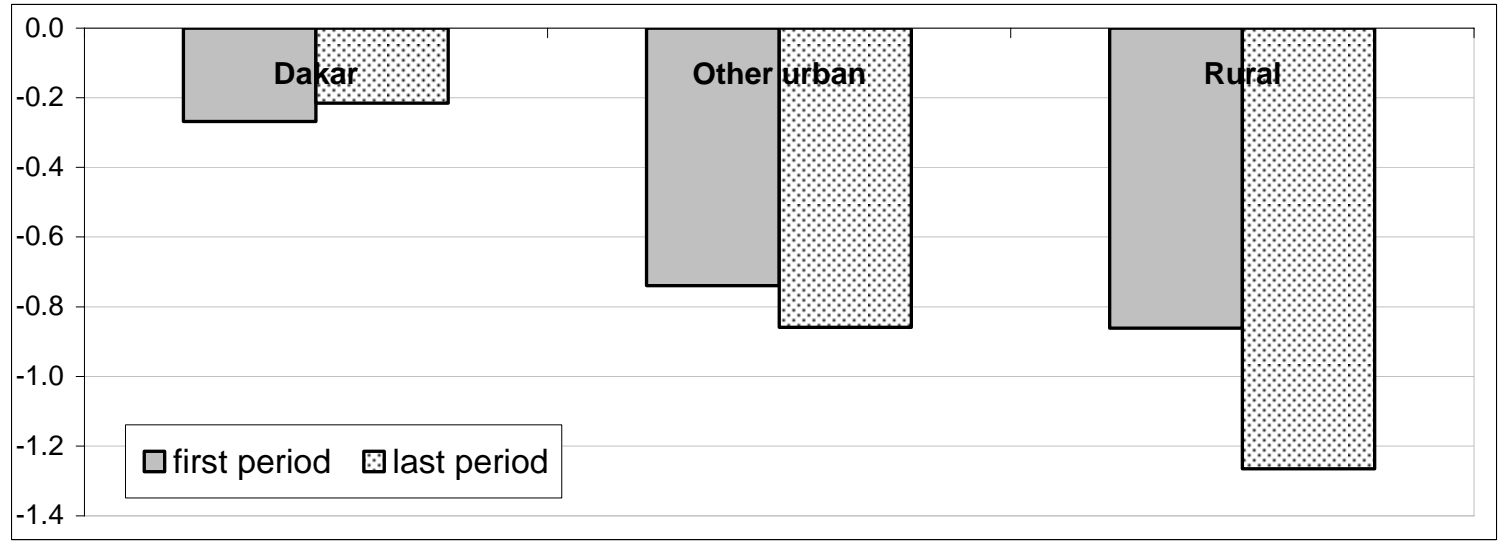

Figure 9: Change in poverty severity by area (percentage points)

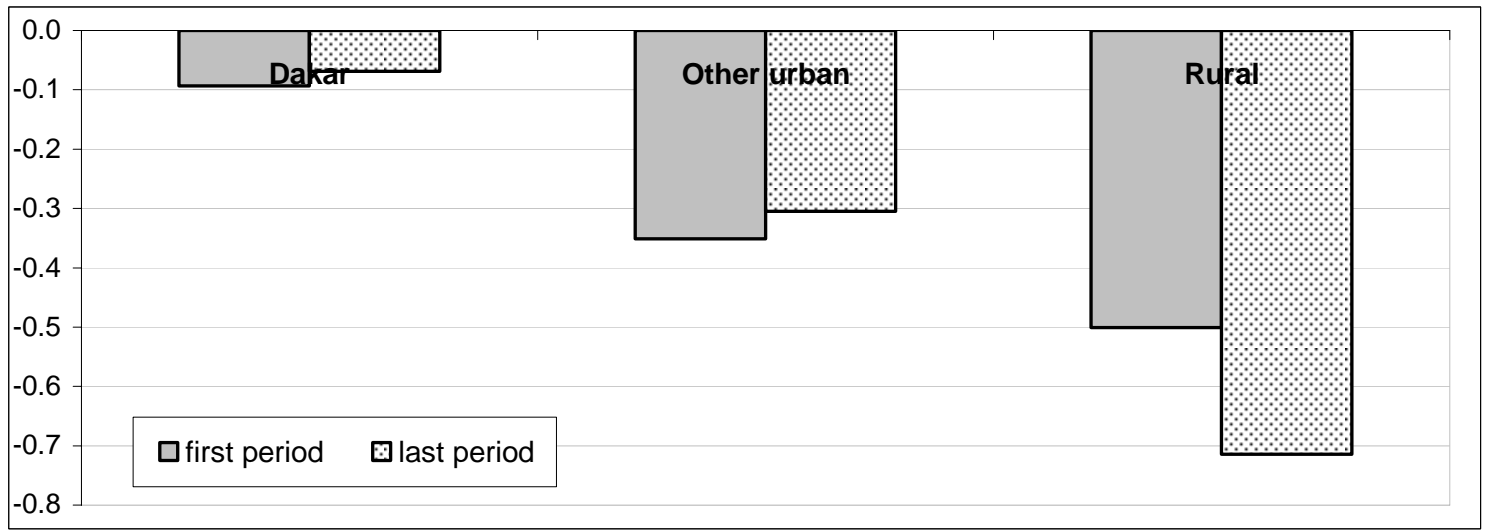

Finally, we explore the gender-specific poverty impacts of the elimination of import tariffs. Recall that we equate the poverty of individuals with that of their household, ignoring important issues of intra-household allocation that go beyond the scope of our analysis. Subject to this important limitation, a clear divergence emerges from the poverty impacts according to the gender of the household head. Male-headed households experience a greater reduction in the incidence and depth of poverty, as shown in Figures 10 and 11. This reflects the slight increase in the over-all gender wage gap as noted in section 5.2.6. Furthermore, as female wage rates fall 
more than male wage rates, particularly in the long term, we may expect that this will harm their intra-household bargaining power such that actual poverty effects will be more skewed against women if this phenomenon was taken into account.

Figure 12: Differences in the impacts on poverty incidence by gender of the household head (percentage points)

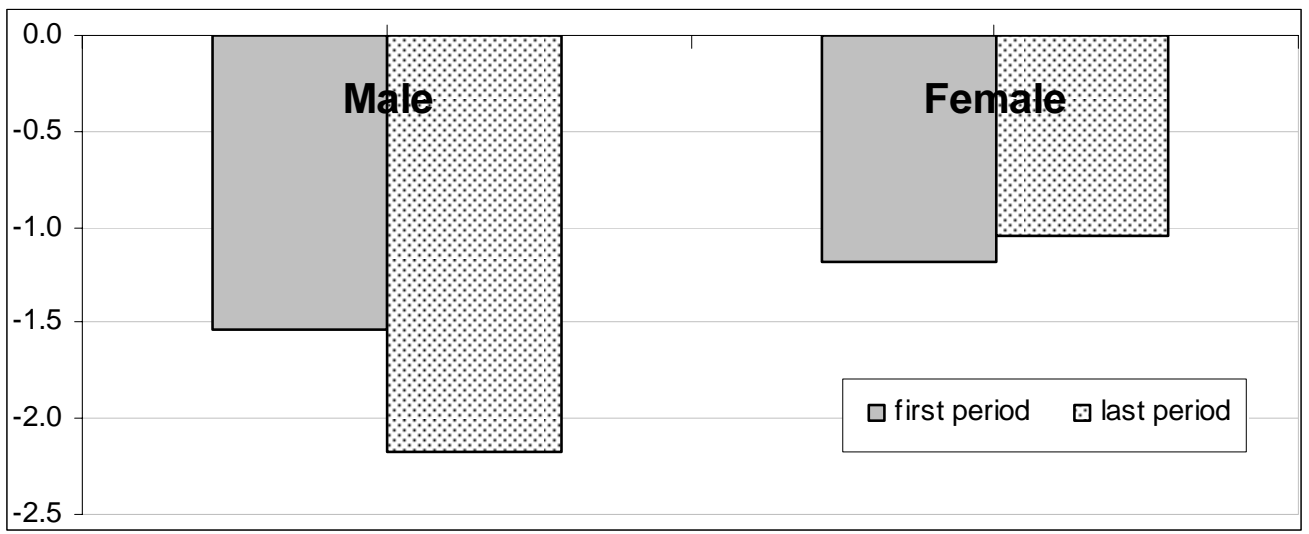

Figure 13: Differences in the impacts on the poverty gap by gender of the household head (percentage points)

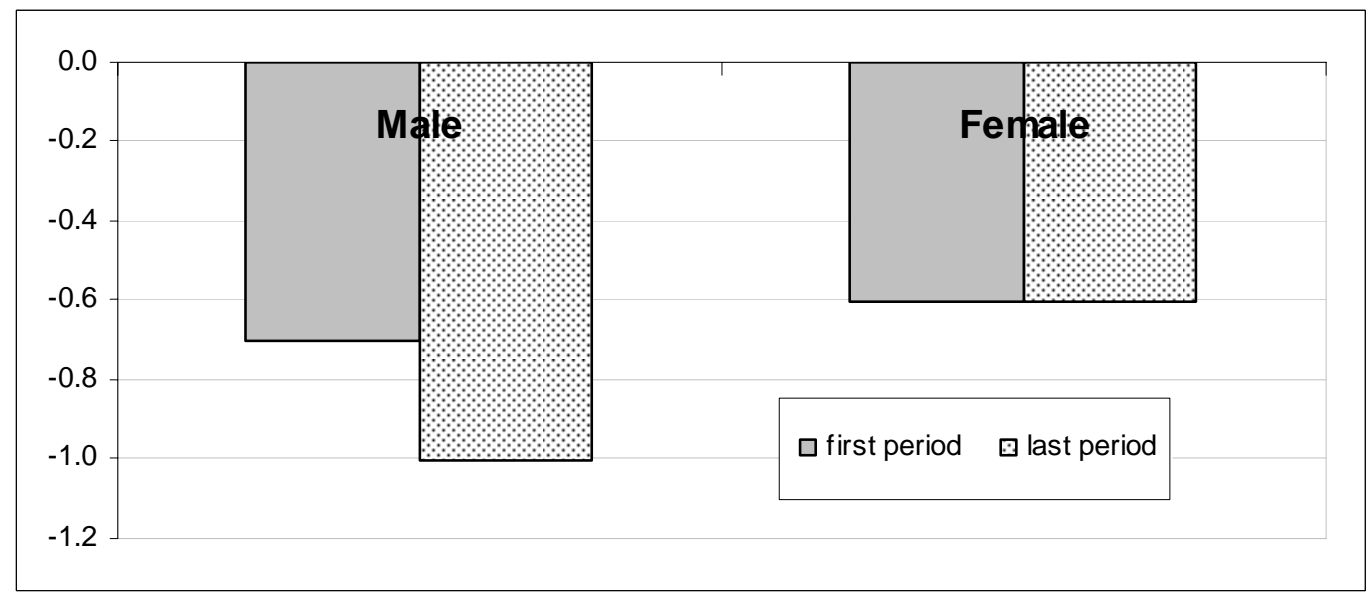

\section{Conclusion}

Senegal is in the process of liberalizing its international trade in the pursuit of higher growth. Our analysis indicates that agricultural workers are likely to gain least from domestic trade liberalization. This is both because the agricultural sector will face a substantial increase in import competition, given moderately high initial protection, and because the sector has limited export opportunities.

However, trade liberalization in Senegal is found to reduce rural poverty more than in urban areas. While the fall in the relative wages of rural workers would initially lead us to believe that rural households would lose the most from trade liberalization, they are in fact compensated by 
greater consumer price savings, given that they consume more goods from the initially protected agricultural and agro-industrial sectors. Whereas urban households, particularly in Dakar, consume more services, for which prices fall only moderately. Nonetheless, when income and consumption channels are brought together, all households post moderate reductions in poverty of up to three percent.

Our gender-specific analysis indicates that trade liberalization increases the over-all gender wage gap, albeit marginally, by favoring the relatively more male labor-intensive export industries. Indeed, our poverty analysis confirms that male-headed households experience greater poverty reduction relative to their female counterparts.

In addition to the gender-specific analysis, the main contribution of the study is to focus on the growth processes set in motion by trade liberalization. These channels are numerous. Increased openness provides the biggest boost, primarily through its impacts on the productivity and efficiency of domestic producers in these primarily agricultural and industrial sectors (technology transfer, increased competition, etc.). Indeed, when we remove this channel, trade liberalization is found to lead only to a very small - 0.6 percent - increase in GDP relative to the business-as-usual (BAU) scenario by the final year of our 15-year simulations. This increased productivity reduces the demand for factors in these sectors, as less are needed to obtain a given production level. As a result, it is the urban workers, particularly female skilled urban workers, who are employed overwhelmingly in the service sectors, which benefits most from the productivity channel as their wages increase vis-à-vis male skilled urban workers. Indeed, this slight increase vanishes while the over-all wage gap widens whenever the productivity effects are not accounted for. However, the productivity channel is also found to reinforce the pro-urban bias of trade liberalization.

Tariff cuts also reduce capital good prices, allowing greater real investments for a given pool of savings. This channel is also found to have strong growth effects. Indeed, if we were to remove this and the productivity channel, GDP would actually decline as a result of trade liberalization relative to BAU. Increased investment boosts industrial production, both because industry is the most capital-intensive sector and because it also provides the majority of capital goods. The increased supply of capital goods reduces their relative returns and increases the returns to skilled urban workers, who are considered to be complements to capital in the production process. As male workers represent a higher share of skilled workers, this channel emphasizes the gender bias of trade liberalization. It also accentuates the pro-urban bias, given their greater reliance on skilled wage income.

We also examined two other growth channels, which are found to have much weaker impacts. First, an increase in foreign investment driven by increased openness, which creates a more conducive investment environment, and increased real returns to capital. Second, an increase in household savings, also driven by increased real returns to capital. These two channels have only minor factor price and distributive impacts.

In conclusion, we find that trade openness results in higher GDP and a fall in all poverty indices in Senegal. The former is due to the growth motors of trade liberalization while the latter results from a moderate increase in households' real income. The unskilled gender wage gap increases 
whereas the skilled gender wage gap falls. However, male workers continue to gain owing to the presence of male labor-intensive export industries. Thus, this suggests the need to implement policies aimed at increasing both unskilled and skilled women's exposure in labor-intensive export industries, which is currently male dominated. 


\section{References}

Azam, J., M. Dia, C. Tsimpo and Q. (2005), "Has Growth in Senegal After the 1994 Devaluation Been Pro-Poor?”, World Bank, Washington DC, mimeo.

Agarwal, J.P. (1980): “Determinants of Foreign Direct Investment: A Survey”, Weltwirtschaftliches Archiv 116: 739-773

Annabi, N., F. Cissé, J. Cockburn and B. Decaluwé (2005); “Trade Liberalisation, Growth and Poverty in Senegal: a Dynamic Microsimulation CGE Model Analysis”; CIRPEE, Université Laval; Cahier de recherche/Working Paper 05-12

Asiedu, E. (2002): “On the Determinants of Foreign Direct Investment to Developing Countries: Is Africa Different?”, World Development 30 (1): 107-119

Baldwin, R.E. (2005). 'Heterogeneous firms and trade: testable and untestable properties of the Melitz model', NBER Working Paper 11471, 1-25

Baldwin, R.E. and F. Robert-Nicoud (2006). 'Trade and growth with heterogeneous firms', CEP Discussion Paper No 727, 1-22.

Bernard, A., J. Eaton, J. Jensen and S. Kortum (2003). 'Plants and productivity in international trade', American Economic Review 93, 1268-90.

Boccanfuso, D., F. Cabral, F. Cissé, A. Diagne and L. Savard ; (2003), "Pauvreté et distribution de revenus au Sénégal: une approche par la modélisation en équilibre général calculable micro-simulé”, Working Paper 03-33, CIRPEE, Universite Laval

Bourguignon F., Robillard A.S. et Robinson S. (2001). “Crisis and Income Distribution : A Micro Macro Model for Indonesia”, The World Bank. Mimeo.

Bourguignon, F. and F. Ferreira; (2005); "Decomposing Changes in the Distribution of Household Incomes: Methodological Aspects.” In F. Bourguignon, F. H. G. Ferreira, and N. Lustig, eds., The Microeconomics of Income Distribution Dynamics in East Asia and Latin America. New York: Oxford University Press.

Cockburn, J., B. Decaluwé and V. Robichaud (2007), "Trade Liberalization and Poverty Lessons from Africa and Asia" in Trade and Investment Division (United Nations Economic Commission for Asia and the Pacific (UNESCAP)), Future Trade Research Areas That Matter To Developing Country Policymakers, Studies in Trade and Investment 61, UNESCAP. http://www.unescap.org/publications/detail.asp?id=1254

Cogneau, D. and A. Robillard (2000). "Income Distribution, Poverty and Growth in Madagascar: Micro Simulations in a General Equilibrium Framework.” IFPRI TMD Discussion Paper No. 61.

de Melo, J. et J.-M. Grether (1997): Commerce international - Théories et applications, De Boeck Université, Bruxelles et Paris

Dollar, D. and A. Kraay (2001), "Growth Is Good for the Poor," World Bank Policy Research Department Working Paper No. 2587, Washington.

Essama-Nssah, B., D. Go, M. Kearney, V. Korman, S. Robinson and K. Thierfelder (2007), "Economy-wide and Distributional Impacts of an Oil Price Shock on the South African Economy”, World Bank Policy Research Working Paper No. 4354; Washington, DC, The World Bank.

Ezenwe, U. (1982), “Trade and Growth in West Africa in the 1980s” The Journal of Modern African Studies, Vol. 20, No. 2. (Jun., 1982), pp. 305-322. 
Fofana, I., Cockburn, J., Decaluwe, B., Diagne, A., Cissé, F., and Cabral, J. F. (2005), "Liberalisation Commerciale et Pauvreté en Afrique: Le cas du Sénégal”, Poverty and Economic Policy, Mimeo.

Fofana I., and F.J. Cabral (2007), « La Matrice de Comptabilité Sociale du Sénégal pour l’Année 2004 », mimeo, PEP and CIRPEE, Université Laval.

Gustafsson, P. and P. Segerstrom (2007). 'Trade liberalization and productivity growth', CEPR Discussion Paper No 5894, 1-36.

Helpman, E., M. Melitz and S.R. Yeaple (2004). 'Export versus FDI with heterogeneous firms', American Economic Review 94, 300-17.

International Bank for Reconstruction and Development/World Bank (2005), "Pro-Poor Growth in the 1990s, Lessons and Insights from 14 Countries” Pro-Poor Growth Research Program” Washington, DC 20433, USA

Kandiero, T. and M. Chitiga (2003): Trade Openness and Foreign Direct Investment in Africa, paper prepared for the Economic Society of Southern Africa 2003 Annual Conference, Cape Town. Published in SAJEMS NS 9 (2006), 3: 335-370

Keller, W. (2000). 'Do trade patterns and technology flows affect productivity growth?', The World Bank Economic Review, 14(1), 117-47.

Kim, E. (2000). 'Trade liberalization and productivity growth in Korean manufacturing industries: price protection, market power, and scale efficiency', Journal of Development Economics 61, 55-83.

Lizondo, J.S. (1990): Foreign Direct Investment, WP/90/63, Research Department, IMF, Washington, DC

Maertens, M. and J.F.M. Swinnen (2006), “Trade, Standards, and Poverty: Evidence from Senegal”, LICOS Discussion Paper 177/2006, LICOS Centre for Institutions and Economic Performance, University of Leuven.

Markusen, J.R. and L.E.O. Svensson (1985): "Trade in Goods and Factors with International Differences in Technology”, International Economic Review 26: 175-192

Markusen, J.R. and J.R. Melvin (1988): The Theory of International Trade, Harper and Row, New York, NY

Martens, A. (2007): “Trade Liberalization and Foreign Direct Investment (FDI) in Emerging Countries: An Empirical Survey”, mimeo, Université de Montréal, Canada.

Melitz, M. (2003). 'The impact of trade on intra-industry reallocations and aggregate industry productivity', Econometrica 71(6), 1695-1726.

Onyeiwu, S. and H. Shrestha (2004): "Determinants of Foreign Direct Investment in Africa”, Journal of Development Studies 20 (1-2): 89-106

Ravallion, M. and M. Lokshin (2004); “Gainers and losers from Trade Reform in Morocco”; World Bank Policy Research Working Paper. No. 3368, Washington, DC.: The World Bank.

Savard, L. (2006) ; "Analyse de la pauvreté et distribution des revenus dans le cadre de la modélisation en équilibre général calculable "; Ph. D dissertation, Ecole des Hautes Etudes en Sciences Sociales.

Winters, A. (2004). 'Trade liberalization and economic performance: an overview', The Economic Journal 114, F4-F21.

Wong, K. (1986): “Are International Trade and Factor Mobility Substitutes?”, Journal of

International Economics 21 (1-2): 25-44 
Annex 1: Structure of the external trade (percent)

\begin{tabular}{|c|c|c|c|c|c|c|}
\hline & $\begin{array}{r}\text { Secto } \\
\text { Value added } \\
\end{array}$ & $\begin{array}{l}\text { ral shares } \\
\text { Imports }\end{array}$ & Exports & $\begin{array}{r}\mathrm{Ra} \\
\text { Imports/Cons. }\end{array}$ & $\begin{array}{l}\text { atios } \\
\text { Exports/Output }\end{array}$ & $\begin{array}{l}\text { Initial } \\
\text { tariffs }\end{array}$ \\
\hline Subsistence & 4.4 & 5.2 & 0.5 & 21.4 & 1.5 & 18.3 \\
\hline Cash crops & 2.4 & 0.9 & 0.5 & 7.8 & 2.8 & 12.5 \\
\hline Livestock & 3.8 & 0.0 & 0.1 & 0.3 & 0.6 & 13.5 \\
\hline Forestry & 1.1 & 0.4 & 0.1 & 8.4 & 1.9 & 11.2 \\
\hline Fishery & 2.5 & 0.4 & 5.4 & 5.5 & 30.9 & 1.4 \\
\hline Mining & 1.5 & 12.5 & 2.7 & 70.5 & 24.4 & 2.2 \\
\hline PRIMARY & 15.7 & 19.3 & 9.3 & 26.2 & 8.5 & 7.1 \\
\hline Meat products & 4.6 & 1.2 & 8.9 & 7.9 & 27.7 & 20.2 \\
\hline Grain products & 1.1 & 8.1 & 0.4 & 26.4 & 1.0 & 22.5 \\
\hline Food processing & 1.2 & 11.4 & 4.7 & 38.5 & 14.0 & 23.3 \\
\hline Beverages & 0.2 & 0.7 & 0.1 & 18.7 & 1.8 & 23.5 \\
\hline Tobacco & 0.2 & 0.0 & 0.7 & 0.4 & 15.9 & 21.1 \\
\hline Textiles & 1.1 & 2.9 & 1.9 & 22.2 & 10.7 & 16.4 \\
\hline Leather & 0.3 & 0.5 & 0.2 & 31.5 & 10.8 & 24.9 \\
\hline Wood products & 0.7 & 0.6 & 0.2 & 13.9 & 3.9 & 14.3 \\
\hline Paper products & 0.7 & 2.1 & 0.0 & 29.1 & 0.0 & 14.2 \\
\hline Petroleum products & 0.6 & 0.3 & 12.7 & 2.5 & 41.9 & 28.0 \\
\hline Chemical products & 2.7 & 12.5 & 18.3 & 69.5 & 67.6 & 14.0 \\
\hline Rubber products & 0.6 & 2.1 & 1.3 & 40.9 & 21.0 & 14.9 \\
\hline Glass products & 1.2 & 2.3 & 2.0 & 25.3 & 15.2 & 14.1 \\
\hline Metal products & 1.0 & 7.1 & 2.5 & 64.2 & 28.4 & 12.3 \\
\hline Machinery & 0.1 & 13.9 & 0.0 & 91.6 & 0.0 & 13.3 \\
\hline Transport material & 0.1 & 5.9 & 0.0 & 92.7 & 0.0 & 15.9 \\
\hline Other manufacturing & 1.7 & 1.2 & 0.5 & 16.4 & 4.8 & 20.0 \\
\hline Utilities & 2.9 & 0.0 & 0.0 & 0.0 & 0.0 & 0.0 \\
\hline Construction & 4.8 & 0.0 & 0.0 & 0.0 & 0.0 & 0.0 \\
\hline INDUSTRIAL & 25.7 & 72.9 & 54.5 & 44.4 & 18.6 & 16.7 \\
\hline Trade & 18.4 & 0.0 & 0.0 & 0.0 & 0.0 & 0.0 \\
\hline Hospitality & 0.9 & 0.0 & 15.2 & 0.0 & 69.6 & 0.0 \\
\hline Transport & 4.3 & 2.0 & 5.4 & 8.3 & 13.6 & 0.0 \\
\hline Telecommunications & 5.6 & 1.0 & 5.5 & 4.8 & 14.5 & 0.0 \\
\hline Finances & 6.0 & 4.5 & 7.0 & 13.7 & 13.5 & 0.0 \\
\hline Real estate & 9.3 & 0.0 & 0.0 & 0.0 & 0.0 & 0.0 \\
\hline Public administration & 7.4 & 0.0 & 0.0 & 0.0 & 0.0 & 0.0 \\
\hline Education & 2.6 & 0.2 & 0.0 & 1.8 & 0.1 & 0.0 \\
\hline Health & 1.3 & 0.0 & 0.0 & 0.2 & 0.1 & 0.0 \\
\hline Other services & 2.7 & 0.0 & 3.0 & 0.1 & 21.0 & 0.0 \\
\hline SERVICES & 58.6 & 7.7 & 36.3 & 8.4 & 18.1 & 0.0 \\
\hline TOTAL & 100.0 & 100.0 & 100.0 & 30.9 & 18.4 & 13.6 \\
\hline
\end{tabular}


Annex 2: Sectoral responses

\begin{tabular}{|c|c|c|c|c|c|c|c|c|c|c|c|c|c|c|c|c|c|c|c|c|}
\hline & \multicolumn{10}{|c|}{ VALUE-ADDED PRICES } & \multicolumn{10}{|c|}{ VALUE ADDED (Volume) } \\
\hline & \multicolumn{5}{|c|}{ First year } & \multicolumn{5}{|c|}{ Last year } & \multicolumn{5}{|c|}{ First year } & \multicolumn{5}{|c|}{ Last year } \\
\hline & Full & $\mathrm{NoPe}$ & NoFS & NoHS & NoPk & Full & $\mathrm{NoPe}$ & NoFS & NoHS & NoPk & Full & $\mathrm{NoPe}$ & NoFS & NoHS & NoPk & Full & $\mathrm{NoPe}$ & NoFS & NoHS & NoPk \\
\hline Subsistence & -12.0 & -7.1 & -12.1 & -12.0 & -12.0 & -10.3 & -6.9 & -10.3 & -10.3 & -10.5 & 0.1 & -6.2 & 0.2 & 0.5 & 0.1 & -0.1 & -6.1 & -0.2 & -0.4 & -1.3 \\
\hline Cash crops & -9.7 & -6.2 & -9.8 & -9.6 & -9.7 & -7.7 & -5.6 & -7.6 & -7.7 & -7.8 & 1.2 & -1.5 & 1.3 & 1.3 & 1.2 & 0.7 & -1.7 & 0.6 & 0.6 & 0.1 \\
\hline Livestock & -14.8 & -7.4 & -15.3 & -14.7 & -14.8 & -9.7 & -2.4 & -9.6 & -9.8 & -10.1 & 5.0 & 0.4 & 5.1 & 5.1 & 5.0 & 5.7 & -0.9 & 5.4 & 5.4 & 4.2 \\
\hline Forestry & -11.3 & -7.2 & -11.4 & -11.3 & -11.3 & -8.2 & -6.5 & -7.9 & -7.9 & -7.2 & 1.6 & -0.7 & 1.6 & 1.7 & 1.6 & 1.1 & -0.9 & 0.9 & 0.8 & 0.1 \\
\hline Fishery & 0.6 & -0.7 & 0.5 & 0.8 & 0.6 & -4.6 & -0.8 & -4.2 & -4.2 & -3.3 & 4.3 & 3.1 & 4.5 & 4.2 & 4.3 & 12.1 & 2.7 & 11.2 & 11.3 & 8.6 \\
\hline Mining & 0.2 & -0.2 & 0.2 & 0.1 & 0.2 & -1.1 & -4.0 & -1.1 & -1.0 & -1.1 & 2.8 & 3.2 & 3.0 & 2.7 & 2.8 & 7.1 & 11.8 & 6.2 & 6.2 & 4.2 \\
\hline PRIMARY & -10.0 & -5.8 & -10.2 & -9.9 & -10.0 & -8.1 & -4.6 & -8.0 & -8.1 & -8.1 & 2.3 & -1.6 & 2.4 & 2.5 & 2.3 & 3.6 & -1.2 & 3.3 & 3.3 & 2.0 \\
\hline Meat products & -7.0 & -4.2 & -7.0 & -6.8 & -7.0 & -7.4 & -1.4 & -7.0 & -7.0 & -6.2 & 7.6 & 1.4 & 7.8 & 7.6 & 7.6 & 12.2 & $\begin{array}{l}-1.4 \\
\end{array}$ & 11.3 & 11.3 & 8.5 \\
\hline Grain products & -18.5 & -10.8 & -18.5 & -18.4 & -18.5 & -12.8 & -8.8 & -12.8 & -12.8 & -13.1 & -0.3 & -5.0 & -0.3 & 0.0 & -0.3 & -0.7 & -5.5 & -0.8 & -0.9 & -2.0 \\
\hline Food processing & -16.0 & -9.3 & -16.0 & -15.9 & -16.0 & -11.3 & -8.0 & -11.3 & -11.4 & -11.7 & 0.2 & -5.6 & 0.4 & 0.4 & 0.2 & -1.2 & -6.7 & -1.3 & -1.3 & -2.5 \\
\hline Beverages & -21.1 & -9.9 & -21.2 & -21.0 & -21.1 & -14.5 & -8.2 & -14.5 & -14.6 & -14.8 & -0.2 & -4.5 & -0.2 & 0.2 & -0.2 & -0.2 & -4.3 & -0.2 & -0.4 & -1.5 \\
\hline Tobacco & -12.0 & -3.0 & -12.6 & -11.5 & -12.0 & -6.6 & 2.8 & -6.2 & -6.6 & -6.1 & 5.0 & 1.5 & 5.2 & 5.3 & 5.0 & 5.8 & 1.4 & 5.7 & 5.6 & 4.2 \\
\hline Textiles & -12.2 & -6.8 & -12.3 & -12.2 & -12.2 & -9.0 & -6.1 & -9.1 & -9.2 & -9.7 & 0.0 & -3.5 & 0.1 & 0.2 & 0.0 & 0.2 & -3.5 & 0.0 & -0.1 & -1.2 \\
\hline Leather & -21.1 & -13.6 & -21.0 & -21.0 & -21.1 & -14.4 & -8.9 & -14.2 & -14.2 & -14.0 & 5.4 & -2.4 & 5.3 & 5.5 & 5.4 & 1.0 & -6.9 & 0.6 & 0.5 & -1.3 \\
\hline Wood products & -11.1 & -7.9 & -11.3 & -11.2 & -11.1 & -8.9 & -6.6 & -8.8 & -8.9 & -8.9 & 2.4 & -2.2 & 2.2 & 2.3 & 2.4 & 1.4 & -3.3 & 0.7 & 0.7 & -0.2 \\
\hline Paper products & -16.9 & -12.4 & -16.9 & -16.9 & -16.9 & -10.2 & -7.7 & -10.1 & -10.0 & -9.9 & -1.2 & -3.8 & -1.1 & -1.2 & -1.2 & -1.7 & -4.5 & -2.2 & -2.3 & -3.6 \\
\hline Petroleum products & -8.7 & -2.8 & -8.9 & -8.7 & -8.7 & -4.4 & 0.1 & -4.1 & -4.1 & -3.5 & 1.7 & 0.3 & 1.8 & 1.7 & 1.7 & 4.0 & 2.1 & 3.4 & 3.4 & 1.5 \\
\hline Chemical products & 1.4 & 1.6 & 1.5 & 1.4 & 1.4 & 0.3 & -1.0 & 0.3 & 0.3 & 0.0 & 7.5 & 5.1 & 7.7 & 7.6 & 7.5 & 22.6 & 31.2 & 21.1 & 20.9 & 16.3 \\
\hline Rubber products & -8.1 & -6.1 & -8.1 & -8.1 & -8.1 & -6.9 & -6.6 & -6.6 & -6.6 & -6.1 & 3.6 & 0.1 & 3.6 & 3.7 & 3.6 & 4.9 & 2.2 & 4.2 & 4.1 & 2.1 \\
\hline Glass products & -13.9 & -9.7 & -14.5 & -14.7 & -13.9 & -8.8 & -6.4 & -8.5 & -8.5 & -7.9 & 2.3 & -0.3 & 2.0 & 1.9 & 2.3 & 0.3 & -2.4 & -1.0 & -1.0 & -1.6 \\
\hline Metal products & -5.2 & -4.9 & -5.3 & -5.5 & -5.2 & -5.2 & -5.9 & -5.1 & -5.1 & -4.9 & 2.6 & 1.3 & 2.4 & 2.3 & 2.6 & 4.1 & 2.4 & 2.7 & 2.6 & 0.7 \\
\hline Machinery & -15.1 & -13.4 & -15.6 & -15.6 & -15.1 & -9.2 & -8.2 & -9.0 & -9.0 & -9.0 & -1.8 & -4.6 & -2.3 & -2.5 & -1.8 & -3.6 & -6.7 & -4.7 & -4.7 & -5.4 \\
\hline Transport $\mathrm{m}$ & -16.6 & -12.8 & -16.9 & -16.9 & -16.6 & -11.5 & -8.4 & -11.5 & -11.5 & -11.6 & -2.5 & -7.0 & -3.0 & -3.1 & -2.5 & -5.1 & -9.8 & -6.1 & -6.2 & -6.7 \\
\hline Other manufacturing & -18.8 & -11.5 & -18.9 & -18.9 & -18.8 & -12.1 & -6.3 & -11.9 & -11.9 & -11.6 & 3.3 & -2.0 & 3.3 & 3.3 & 3.3 & 1.6 & -3.6 & 1.0 & 0.9 & -0.6 \\
\hline Utilities & -1.7 & -6.5 & -2.0 & -1.3 & -1.7 & -2.3 & -3.6 & -1.9 & -2.1 & -1.3 & 0.8 & -0.3 & 0.8 & 0.9 & 0.8 & 2.9 & 0.5 & 2.5 & 2.4 & 1.0 \\
\hline Construction & -2.2 & -5.8 & -3.6 & -3.5 & -2.2 & -2.4 & -4.1 & -2.1 & -2.2 & -2.0 & 1.9 & 0.1 & 0.9 & 0.7 & 1.9 & 2.2 & -0.6 & 0.7 & 0.6 & 0.6 \\
\hline INDUSTRIAL & -7.9 & -6.2 & -8.2 & -8.1 & -7.9 & -6.0 & -4.4 & -5.8 & -5.9 & -5.7 & 3.0 & -0.4 & 2.9 & 2.8 & 3.0 & 5.5 & 1.9 & 4.6 & 4.5 & 2.9 \\
\hline Trade & -3.2 & -5.9 & -3.5 & -3.2 & -3.2 & -1.6 & -3.7 & -1.5 & $\begin{array}{ll}-1.6 \\
\end{array}$ & -1.7 & 1.5 & 0.0 & 1.5 & 1.5 & 1.5 & 3.6 & 0.6 & 3.0 & 2.9 & 1.5 \\
\hline Hospitality & 3.0 & 1.4 & 2.8 & 3.0 & 3.0 & -1.2 & -2.4 & -1.3 & -1.3 & -1.7 & 12.8 & 10.8 & 13.2 & 12.8 & 12.8 & 20.1 & 13.4 & 19.5 & 19.7 & 17.6 \\
\hline Transport & -3.0 & -4.3 & -3.3 & -3.0 & -3.0 & -2.6 & -2.9 & -2.4 & -2.6 & -2.4 & 2.9 & 2.2 & 3.0 & 2.9 & 2.9 & 4.9 & 2.4 & 4.3 & 4.3 & 2.8 \\
\hline Telecommunications & -5.4 & -5.3 & -5.8 & -5.2 & -5.4 & -3.7 & -0.6 & -3.4 & -3.7 & -3.4 & 3.6 & 2.5 & 3.9 & 3.7 & 3.6 & 4.7 & 0.0 & 4.3 & 4.4 & 2.9 \\
\hline Finances & 0.1 & -2.0 & -0.1 & -0.1 & 0.1 & -0.7 & -4.0 & -0.9 & -1.0 & -1.6 & 2.1 & 2.1 & 2.1 & 1.9 & 2.1 & 4.0 & 3.1 & 3.3 & 3.3 & 2.5 \\
\hline Real estate & -2.4 & -6.2 & -2.6 & -1.8 & -2.4 & -3.2 & -4.2 & -2.5 & -2.7 & -1.3 & 0.1 & 0.0 & 0.1 & 0.1 & 0.1 & 2.2 & -0.1 & 1.8 & 1.7 & 0.2 \\
\hline Public administration & -4.3 & -6.0 & -4.6 & -4.3 & -4.3 & -1.8 & -3.7 & -1.7 & -1.8 & -1.8 & 0.0 & 0.0 & 0.0 & 0.0 & 0.0 & 0.0 & 0.0 & 0.0 & 0.0 & 0.0 \\
\hline Education & -2.1 & -5.3 & -2.3 & -2.1 & -2.1 & -0.5 & -5.8 & -0.6 & -0.7 & -1.2 & -1.1 & -0.7 & -1.1 & -0.7 & -1.1 & 0.0 & 0.4 & 0.0 & -0.2 & -0.9 \\
\hline Health & -3.6 & -6.1 & -3.8 & -3.5 & -3.6 & -1.4 & -4.8 & -1.4 & -1.6 & -2.0 & 0.0 & -0.3 & -0.1 & 0.3 & 0.0 & 0.9 & -0.1 & 0.9 & 0.7 & -0.1 \\
\hline Other services & -9.9 & -7.1 & -10.3 & -8.9 & -9.9 & -6.8 & 5.6 & -5.9 & -6.2 & -4.3 & 7.5 & 4.1 & 7.9 & 6.9 & 7.5 & 8.8 & -6.0 & 7.5 & 7.7 & 4.1 \\
\hline SERVICES & -3.2 & -5.2 & -3.5 & -3.1 & -3.2 & -2.1 & -3.3 & -1.9 & -2.0 & -1.9 & 1.7 & 0.9 & 1.7 & 1.7 & 1.7 & 3.4 & 0.8 & 2.9 & 2.9 & 1.7 \\
\hline TOTAL & -5.5 & -5.6 & -5.8 & -5.5 & -5.5 & -4.1 & -3.8 & -3.9 & -4.0 & -3.9 & 2.1 & 0.1 & 2.1 & 2.1 & 2.1 & 3.9 & 0.7 & 3.4 & 3.3 & 2.0 \\
\hline
\end{tabular}


Annex 3: Factor prices

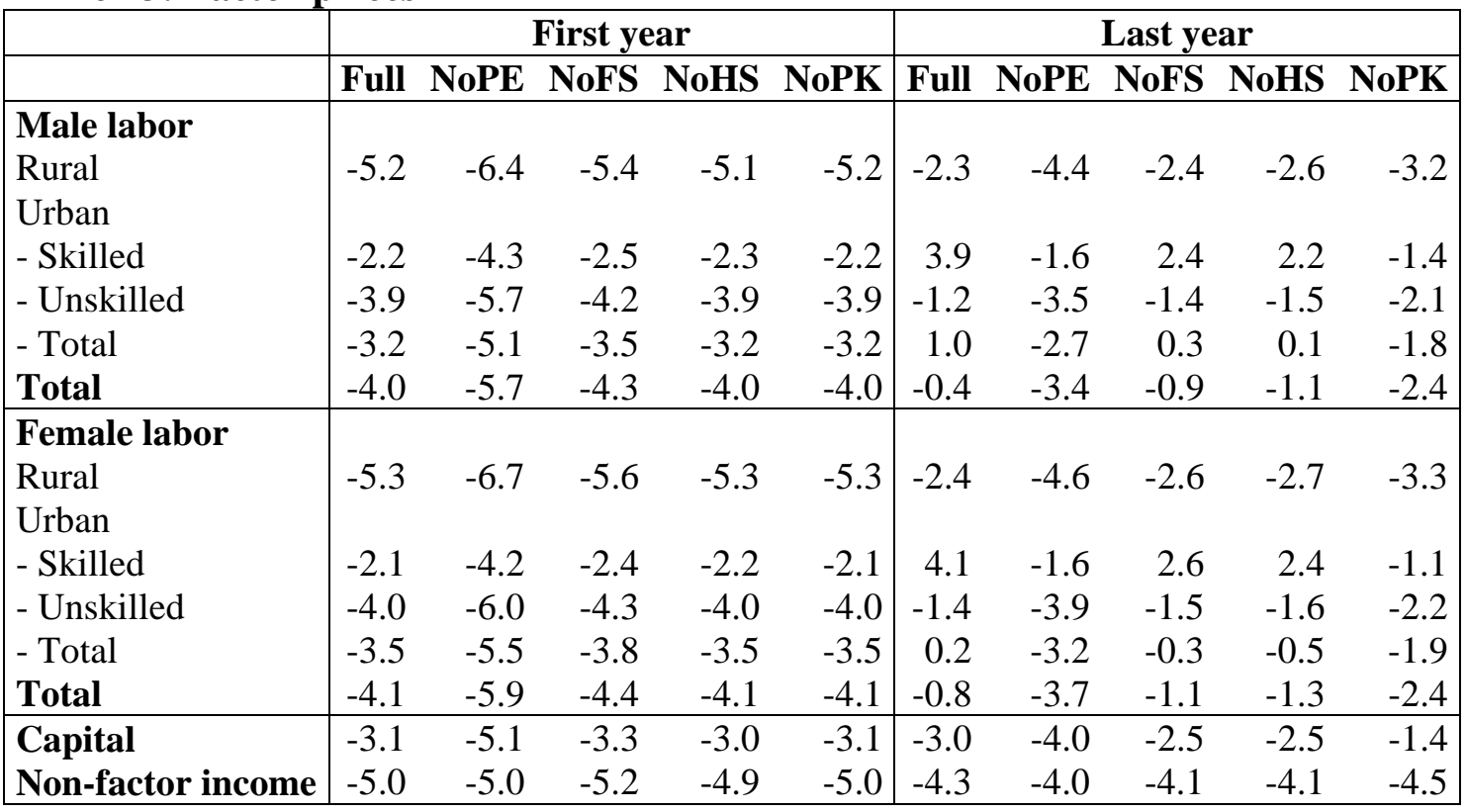

Notes: BAU = Business as usual; Full: Core simulation (all growth channels); NoPE = No productivity/efficiency channel; NoFS = No FS channel; NoHS = No returns to capital effect on household savings; NoPK = No capital good price effect

\section{Annex 4: The structure of the model}

\subsection{Production}

1. $X S_{i, t}=V A_{i, t} / v_{i}$

2. $C I_{i, t}=i o_{i} \cdot X S_{i, t}$

3. $D I_{i, j, t}=a i j_{i, j} \cdot C I_{j, t}$

4. $V A_{i, t}=A_{i}^{V A} \cdot \theta_{i, t} \cdot\left(\alpha_{i}^{V A} \cdot L N Q_{i, t}^{-\nu_{i}^{V A}}+\left(1-\alpha_{i}^{V A}\right) \cdot K L Q_{i, t}^{-\rho_{i}^{V A}}\right)^{-1 / \rho_{i}^{V A}}$

5. $\theta_{i, t}=\left[\frac{\left(I M_{i, t}+E X_{i, t}\right) / V A_{i, t}}{\left(I M_{i}^{0}+E X_{i}^{0}\right) / V A_{i}^{0}}\right]^{\sigma^{P T}}$ or $\theta_{i, t}=1$ if $E X_{i}^{0}=I M_{i}^{0}=0$

6. $L N Q_{i, t}=\left[\frac{\alpha_{i}^{V A}}{\left(1-\alpha_{i}^{V A}\right)} \cdot \frac{P K L Q_{i, t}}{w n q_{i, t}}\right]^{\sigma_{i}^{V A}} \cdot K L Q_{i, t}$

7. $L N Q_{i, t}=A_{i}^{L N Q} \cdot\left(\alpha_{i}^{L N Q} \cdot L D T_{U N Q, i, t}^{-\rho_{i}^{L N Q}}+\left(1-\alpha_{i}^{L N Q}\right) \cdot L D T_{R N Q, i, t}^{-\rho_{i}^{L N Q}}\right)^{-1 / \rho_{i}^{L N Q}}$

8. $L D T_{U N Q, i, t}=\left[\frac{\alpha_{i}^{L N Q}}{\left(1-\alpha_{i}^{L N Q}\right)} \cdot \frac{w t_{R N Q, i, t}}{w t_{U N Q, i, t}}\right]^{\sigma_{i}^{L N Q}} \cdot L D T_{R N Q, i, t}$

9. $K L Q_{i, t}=A_{i}^{K L} \cdot\left(\alpha_{i}^{K L} \cdot L Q_{i, t}^{-\rho_{i}^{K L}}+\left(1-\alpha_{i}^{K L}\right) \cdot K D_{i, t}^{-\rho_{i}^{K L}}\right)^{-1 / \rho_{i}^{K L}}$ 
10. $L Q_{i, t}=\left[\frac{\alpha_{i}^{K L}}{\left(1-\alpha_{i}^{K L}\right)} \cdot \frac{r_{i, t}}{w q_{i, t}}\right]^{\sigma_{i}^{K L}} \cdot K D_{i, t}$

11. $L Q_{i, t}=A_{i}^{L Q} \cdot\left(\alpha_{i}^{L Q} \cdot L D T_{U Q, i, t}^{-\rho_{i}^{L Q}}+\left(1-\alpha_{i}^{L Q}\right) \cdot L D T_{R Q, i, t}^{-\rho_{i}^{L Q}}\right)^{-1 /} \rho_{i}^{L Q}$

12. $L D T_{U Q, i, t}=\left[\frac{\alpha_{i}^{L Q}}{\left(1-\alpha_{i}^{L Q}\right)} \cdot \frac{w t_{R Q, i, t}}{w t_{U Q, i, t}}\right]^{\sigma_{i}^{L Q}} \cdot L D T_{R Q, i, t}$

13. $L D T_{l, i, t}=A_{l, i}^{L G} \cdot\left(\alpha_{l, i}^{L G} \cdot F L D T_{l, i, t}^{-\rho_{l, i}^{L G}}+\left(1-\alpha_{i}^{L G}\right) \cdot M L D T_{l, i, t}^{-\rho_{l, i}^{L G}}\right)^{-1 / 1} \rho_{l, i}^{L G}$

14. $F L D T_{l, i, t}=\left[\frac{\alpha_{l, i}^{L G}}{\left(1-\alpha_{l, i}^{L G}\right)} \cdot \frac{w m_{l, t}}{w f_{l, t}}\right]^{\sigma_{l, i}^{L G}} \cdot M L D T_{l, i, t}$

15. $G D P_{t}=\sum_{I} P V_{i}^{0} \cdot V A_{i, t}$

\subsection{Income and Savings}

16.

$$
\begin{aligned}
Y H_{h, t} & =\sum_{L}\left(w f_{l, t} \cdot F L S_{h, l, t}+w m f_{l, t} \cdot M L S_{h, l, t}\right)+\left(K H_{h, t} / K S_{t}\right) \cdot \sum_{I} r_{i, t} \cdot K D_{i, t} \\
& +P I N D E X_{t} \cdot T G_{h, t}+D I V_{h, t}+e_{t} \cdot T R O W_{-} H_{h, t}
\end{aligned}
$$

17. $Y D H_{h, t}=Y H_{h, t}-D T H_{h, t}$

18. $S H_{h, t}=\psi_{h} \cdot\left[\frac{r m o y_{t} / \text { PINDEX }_{t}}{r m o y^{0} / \text { PINDEX }}\right]^{\sigma_{h}^{H S}} \cdot Y D H_{h, t}$

19. $Y F_{t}=\left(K F_{t} / K S_{t}\right) \cdot \sum_{I} r_{i, t} \cdot K D_{i, t}+P I N D E X_{t} \cdot T G_{-} F_{t}+e_{t} \cdot T R O W_{-} F_{t}$

20. $S F_{t}=Y F_{t}-D T F_{t}-\sum_{H} D I V_{h, t}-D I V_{-} R O W_{t}$

21. $D I V_{h, t}=\frac{D I V_{h}^{0}}{Y F^{0}} \cdot Y F_{t}$

22. $D I V_{-} R O W_{t}=\frac{D I V_{-} R O W^{0}}{Y F^{0}} \cdot Y F_{t}$

$$
Y G_{h, t}=\sum_{I}\left(T I_{i, t}+T I P_{i, t}\right)+\sum_{H} D T H_{h, t}+\sum_{X} T I X_{x, t}+\sum_{M} T I M_{m, t}+D T F_{t}
$$

23.

$$
\left(K G_{t} / K S_{t}\right) \cdot \sum_{I} r_{i, t} \cdot K D_{i, t}+e_{t} \cdot T R O W_{-} G_{t}
$$

24. $S G_{t}=Y G_{t}-\sum_{I} P C_{i, t} \cdot G_{i, t}-\sum_{H} P I N D E X_{t} \cdot T G_{h, t}-P I N D E X_{t} \cdot T G_{-} F_{t}-e_{t} \cdot T G_{-} R O W_{t}$

25. $S G_{t}=\frac{S G^{0}}{G D P^{0}} \cdot G D P_{t}$ 
26. $T I_{m, t}=\left(t x_{m}+t x_{t}^{N E W}\right) \cdot P L_{m, t} \cdot D_{m, t}+\left(t x_{m}+t x_{t}^{N E W}\right) \cdot\left(1+t m_{m}\right) \cdot e_{t} \cdot P W M_{m, t} \cdot I M_{m, t}$

27. $T I_{n m, t}=\left(t x_{n m}+t x_{t}^{N E W}\right) \cdot P L_{n m, t} \cdot D_{n m, t}$

28. $T I P_{i, t}=t p_{i} \cdot P_{i, t} \cdot X S_{i, t}$

29. $T I M_{m, t}=t m_{m} \cdot P W M_{m, t} \cdot e_{t} \cdot I M_{m, t}$

30. $T I X_{x, t}=\operatorname{tex}_{x} \cdot P E_{x, t} \cdot E X_{x, t}$

31. $D T H_{h, t}=t y f_{h} \cdot Y H_{h, t}$

32. $D T F_{t}=t y f \cdot Y F_{t}$

\subsection{Demand}

33. $C_{i, h, t} \cdot P C_{i, t}=C_{i, h, t}^{M I N} \cdot P C_{i, t}+\gamma_{i, h} \cdot\left(Y D H_{h, t}-S H_{h, t}-\sum_{j} C_{j, h, t}^{M I N} \cdot P C_{j, t}\right)$

34. $I N V_{i, t} \cdot P C_{i, t}=\mu_{i} \cdot I T_{t}$

35. $\frac{I N D_{i, t}}{K D_{i, t}}=\phi_{i}\left[\frac{r_{i, t}}{U_{t}}\right]^{\sigma_{i}^{K}}$

36. $D I T_{i, t}=\sum_{J} D I_{i, j, t}$

\subsection{Prices}

37. $\left(1-t p_{i}\right) \cdot P_{i, t} \cdot X S_{i, t}=P V_{i, t} \cdot V A_{i, t}+\sum_{J} P C_{j, t} \cdot D I_{j, i, t}$

38. $P V_{i, t} \cdot V A_{i, t}=r_{i, t} \cdot K D_{i, t}+\sum_{L} w t_{l, i, t} \cdot L D T_{l, i, t}$

39. $P K L Q_{i, t} \cdot K L Q_{i, t}=r_{i, t} \cdot K D_{i, t}+w q_{i, t} \cdot L Q_{i, t}$

40. $w q_{i, t} \cdot L Q_{i, t}=\sum_{Q U} w t_{q u, i, t} \cdot L D T_{q u, i, t}$

41. $w n q_{i, t} \cdot L N Q_{i, t}=\sum_{N Q} w t_{n q, i, t} \cdot L D T_{n q, i, t}$

42. $w t_{l, i, t} \cdot L D T_{l, i, t}=w m_{l, t} \cdot M L D T_{l, i, t}+w f_{l, t} \cdot F L D T_{l, i, t}$

43. $P C_{m, t} \cdot Q_{m, t}=P D_{m, t} \cdot D_{m, t}+P M_{m, t} \cdot I M_{m, t}$

44. $P C_{n m, t}=P D_{n m, t}$

45. $P_{x, t} \cdot X S_{x, t}=P L_{x, t} \cdot D_{x, t}+P E_{x, t} \cdot E X_{x, t}$

46. $P_{n x, t}=P L_{n x, t}$

47. $P D_{i, t}=P L_{i, t} \cdot\left(1+t x_{i}+t x_{t}^{N E W}\right)$

48. $P M_{m, t}=e_{t} \cdot P W M_{m, t} \cdot\left(1+t m_{m}\right) \cdot\left(1+t x_{m}+t x_{t}^{N E W}\right)$

49. $P E_{x, t}=\frac{e_{t} \cdot P W E_{x, t}}{\left(1+t_{x}\right)}$ 
50. PINDEX $X_{t}=\frac{\sum_{I, H} P C_{i, t} \cdot C_{i, h}^{0}}{\sum_{I, H} P C_{i}^{0} \cdot C_{i, h}^{0}}$

51. $r m o y+\frac{\sum_{t} r_{i, t} \cdot K D_{i}^{0}}{\sum_{I} r_{i}^{0} \cdot K D_{i}^{0}}$

52. $P K_{t}=\prod_{I}\left[\frac{P C_{i, t}}{\mu_{i}}\right]^{\mu_{i}}$

53. $U_{t}=P K_{t} \cdot\left(i r_{t}+\delta\right)$

\subsection{International Trade}

54. $X S_{x, t}=B_{x}^{E} \cdot\left(\beta_{x}^{E} \cdot E X_{x, t}^{\kappa_{x}^{E}}+\left(1-\beta_{x}^{E}\right) \cdot D_{x, t}^{\kappa_{x}^{E}}\right)^{1 / \kappa_{x}^{E}}$

55. $X S_{n \times, t}=D_{n x, t}$

56. $E X_{x, t}=\left[\frac{\left(1-\beta_{x}^{E}\right)}{\beta_{x}^{E}} \cdot \frac{P E_{x, t}}{P L_{x, t}}\right]^{\tau_{x}^{E}} \cdot D_{x, t}$

57. $Q_{m, t}=A_{m}^{M} \cdot\left(\alpha_{m}^{M} \cdot I M_{m, t}^{-\rho_{m}^{M}}+\left(1-\alpha_{m}^{M}\right) \cdot D_{m, t}^{-\rho_{m}^{M}}\right)^{-1 / \rho_{m}^{M}}$

58. $Q_{n m, t}=D_{n m, t}$

59. $I M_{m, t}=\left[\frac{\alpha_{m}^{M}}{\left(1-\alpha_{m}^{M}\right)} \cdot \frac{P D_{m, t}}{P M_{m, t}}\right]^{\sigma_{m}^{M}} \cdot D_{m, t}$

60. $C A B_{t}=e_{t} \cdot \sum_{M} P W M_{m, t} \cdot I M_{m, t}+\left(K R O W_{t} / K S_{t}\right) \cdot \sum_{I} r_{i, t} \cdot K D_{i, t}+e_{t} \cdot T G_{-} R O W_{t}+D I V_{-} R O W_{t}$

$$
-e_{t} \cdot \sum_{X} P W E_{x, t} \cdot E X_{x, t}-e_{t} \cdot T R O W_{-} F_{t}-e_{t} \cdot T R O W_{-} G_{t}-e_{t} \cdot \sum_{H} T R O W_{-} H_{h, t}
$$

61. $C A B_{t}=\frac{C A B^{0}}{G D P^{0}} \cdot\left[\frac{r m o y_{t} / \text { PINDEX }_{t}}{r m o y^{0} / \text { PINDEX }^{0}}\right]^{\sigma^{F S R}} \cdot\left[\frac{\left(I M_{t}+E X_{t}\right) / G D P_{t}}{\left(I M^{0}+E X^{0}\right) / G D P^{0}}\right]^{\sigma^{F S O}} G D P_{t}$

\subsection{Equilibrium}

62. $Q_{i, t}=\sum_{H} C_{i, h, t}+G_{i, t}+D I T_{i, t}+I N V_{i, t}$

63. $\sum_{H} M L S_{h, l, t}=\sum_{I} M L D T_{l, i, t}$

64. $\sum_{H} F L S_{h, l, t}=\sum_{I} F L D T_{l, i, t}$

65. $K S_{t}=\sum_{I} K D_{i, t}$ 
66. $I T_{i}=\sum_{H} S H_{h, t}+S G_{t}+S F_{t}+C A B_{t}$

67. $I T_{i}=P K_{t} \cdot \sum_{I} I N D_{i, t}$

\subsection{Dynamic}

68. $K D_{i, t+1}=K D_{i, t}(1-\delta)+I N D_{i, t}$

69. $K H_{h, t+1}=K H_{h, t}(1-\delta)+\left(\frac{S H_{h, t}}{P K_{t}}\right)$

70. $K F_{t+1}=K F_{t}(1-\delta)+\left[\frac{S F_{t}}{I T_{t}}\right] \cdot \sum_{I} I N D_{i, t}$

71. $K G_{t+1}=K G_{t}(1-\delta)+\left[\frac{S G_{t}}{I T_{t}}\right] \cdot \sum_{I} I N D_{i, t}$

72. $K_{R O W} W_{t+1}=\operatorname{KROW}_{t}(1-\delta)+\left[\frac{C A B_{t}}{I T_{t}}\right] \cdot \sum_{I} I N D_{i, t}$

73. $M L S_{h, l, t+1}=M L S_{h, l, t} \cdot(1+n)$

74. $F L S_{h, l, t+1}=F L S_{h, l, t} \cdot(1+n)$

75. $C_{i, h, t+1}^{M I N}=C_{i, h, t}^{M I N} \cdot(1+n)$

76. $T G_{h, t+1}=T G_{h, t} \cdot(1+n)$

77. $T G_{-} F_{t+1}=T G_{-} F_{t} \cdot(1+n)$

78. $T G_{-} R O W_{t+1}=T G_{-} R O W_{t} \cdot(1+n)$

79. $T R O W_{-} G_{t+1}=$ TROW_ $G_{t} \cdot(1+n)$

80. $T R O W_{-} F_{t+1}=$ TROW $F_{-} \cdot(1+n)$

81. TROW ${ }_{-} H_{h, t+1}=$ TROW ${ }_{-} H_{h, t} \cdot(1+n)$

82. $G_{i, t+1}=G_{i, t} \cdot(1+n)$

\subsection{Parameters}
$A_{i}^{K L}$ :
Scale coefficient (CES capital - skilled labor)
$A_{l, i}^{L G}:$
Scale coefficient (CES labor gender function)
$A_{i}^{L N Q}$ :
Scale coefficient (CES unskilled labor)
$A_{i}^{L Q}$ :
Scale coefficient (CES skilled labor)
$A_{m}^{M}$ :
Scale parameter (CES import function)
$A_{i}^{V A}:$
Scale coefficient (CES value added)
$\operatorname{aij}_{i, j}$ :
Input output coefficient
$\alpha_{i}^{K L}$ :
Share parameter (CES capital - skilled labor) 
$\alpha_{l, i}^{L G}:$

$\alpha_{i}^{L N Q}$ :

$\alpha_{i}^{L Q}$ :

$\alpha_{m}^{M}$ :

$\alpha_{i}^{V A}$ :

$B_{x}^{E}$ :

$\beta_{x}^{E}$ :

$\delta$ :

$\gamma_{i, h}$ :

io ${ }_{i}$ :

$\kappa_{x}^{E}$ :

$\mu_{i}$ :

$n$ :

$\phi_{i}$ :

$\psi_{h}$ :

$\rho_{i}^{K L}$ :

$\rho_{l, i}^{L G}:$

$\rho_{i}^{L N Q}$ :

$\rho_{i}^{L Q}$ :

$\rho_{m}^{M}$ :

$\rho_{i}^{V A}$ :

$\sigma^{F S}$ :

$\sigma^{H S}$ :

$\sigma_{i}^{K}$ :

$\sigma_{i}^{K L}$ :

$\sigma_{l, i}^{L G}$;

$\sigma_{i}^{L N Q}$ :

$\sigma_{i}^{L Q}$ :

$\sigma_{m}^{M}$ :

$\sigma^{P T}$ :

$\sigma_{i}^{V A}:$

$\tau_{x}^{E}$ :

$\mathrm{tm}_{\mathrm{m}}$ :
Share parameter (CES Labor by gender)

Share parameter (CES unskilled labor)

Share parameter (CES skilled labor)

Share parameter (CES import function)

Share parameter (CES value added)

Scale parameter (CET function)

Share parameter (CET function)

Depreciation rate of capital

Marginal share of good I in household $\mathrm{H}$ consumption

Coefficient (Leontief total intermediate consumption)

Transformation parameter (CET export function)

Share of the value of good TR in total investment

Population growth rate

Coefficient in investment demand function

Propensity to save for household $\mathrm{H}$

Substitution parameter (CES capital - skilled labor)

Substitution parameter (CES labor gender function)

Substitution parameter (CES unskilled labor)

Substitution parameter (CES skilled labor)

Substitution parameter (CES import function)

Substitution parameter (CES value added)

Elasticity of foreign savings to rate of return

Elasticity of household savings to rate of return

Investment demand elasticity

Substitution elasticity (CES capital - skilled labor)

Substitution elasticity (CES function between genders)

Substitution elasticity (CES unskilled labor)

Substitution elasticity (CES skilled labor)

Substitution elasticity (CES import function)

Elasticity of scale parameter to openness

Substitution elasticity (CES value added using old capital)

Transformation elasticity (CET export function)

Import duties on good $\mathrm{i}$ 


$\begin{array}{ll}t e x_{x}: & \text { Tax on exports } \\ t p_{i}: & \text { Tax rate on production of sector i } \\ t x_{i}: & \text { Tax rate on good i } \\ t y f: & \text { Direct income tax rate for firms } \\ t y h_{h}: & \text { Direct income tax rate for household h } \\ v_{i}: & \text { Coefficient (Leontief value added) }\end{array}$

\subsection{Endogenous Variables}

$C_{i, h, t}$ : $\quad$ Household H consumption of good I (volume)

$C A B_{t}$ : $\quad$ Current account balance

$C_{i, t}: \quad$ Total intermediate consumption of sector I

$D_{i, t}: \quad$ Demand for domestic good I

$D I_{i, j, t}$ : $\quad$ Intermediate consumption of good I in sector $\mathrm{J}$

$D I T_{i, t}: \quad \quad$ Intermediate demand for good I

$D I V_{h, t}: \quad$ Dividends paid to households

$D I V_{-} R O W_{t}$ : Dividends paid to foreigners

$D T F_{t}$ : $\quad$ Receipts from direct taxation on firms income

$D_{T H}$ : $\quad$ Receipts from direct taxation on household $\mathrm{H}$ income

$E X_{x, t}: \quad$ Exports of good $\mathrm{X}$

$F L D T_{l, i, t}: \quad$ Sector I demand for female labor $\mathrm{L}$

$F L S_{h, l, t}$ : $\quad$ Household $\mathrm{H}$ female labor L supply

$G D P_{t}$ : $\quad$ Gross domestic product at factor cost

$I M_{m, t}: \quad$ Imports of good $\mathrm{M}$

$I N D_{i, t}: \quad$ Investment by destination

$I N V_{i, t}: \quad$ Investment in good I (origin)

$i r_{t}: \quad$ Interest rate

$I T_{t}: \quad$ Total investment (value)

$K L Q_{i, t}$ : $\quad$ Sector I demand for capital skilled labor aggregate

$K S_{t}: \quad$ Total capital stock

$L D T_{l, i, t}: \quad$ Sector I demand for labor $\mathrm{L}$

$L N Q_{i, t}$ : $\quad$ Sector I demand for unskilled labor

$L Q_{i, t}$ : $\quad$ Sector I demand for skilled labor

$M L D T_{l, i, t}: \quad$ Sector I demand for male labor $\mathrm{L}$ 
$M L S_{h, l, t}$ : $\quad$ Household H male labor L supply

$P_{i, t}: \quad \quad \quad \quad$ Producer price of good I

$P C_{i, t}: \quad \quad \quad \quad$ Price of composite good I

$P D_{i, t}$ : $\quad$ Domestic price of good I including tax

$P E_{x, t}: \quad$ Domestic price of exported good $\mathrm{X}$

PINDEX $_{t}: \quad$ Consumer price index

$P K_{t}$ : $\quad$ Capital replacement price

$P K L Q_{i, t}$ : $\quad$ Price of the capital skilled labor aggregate

$P L_{i, t}$ : $\quad$ Domestic price of good I excluding tax

$P M_{m, t}: \quad \quad$ Domestic price of imported good I

$P V_{i, t}: \quad$ Value added price for sector I

$Q_{i, t}: \quad$ Demand for composite good I

$r_{i, t}$ : $\quad$ Rate of return to capital in sector I

rmoy $_{t}: \quad$ Average rate of return

$S F_{t}: \quad$ Firm savings

$S G_{t}: \quad$ Government savings

$\mathrm{SH}_{h, t}: \quad$ Household H savings

$\theta_{i, t}: \quad$ Productivity factor

$T I_{i, t}$ : $\quad$ Receipts from indirect tax

TIP $P_{i, t}$ : $\quad$ Receipts from tax on production

TIM $_{m, t}: \quad$ Receipts from import duties

TIX ${ }_{x, t}: \quad$ Receipts from tax on production

$t x_{t}^{N E W}: \quad \quad$ New tax on goods and services to keep SG constant

$U_{t}: \quad$ Capital user cost

$V A_{i, t}: \quad \quad$ Value added in sector I (volume)

$w f_{l, t}: \quad$ Wage rate for male worker of type $\mathrm{L}$

$w m_{l, t}$ : Wage rate for male worker of type $\mathrm{L}$

$w n q_{i, t}: \quad \quad$ Average wage rate for unskilled workers

$w q_{i, t}: \quad$ Average wage rate for skilled workers

$w t_{l, i, t}: \quad$ Average wage rate for sector I and labor type $\mathrm{L}$

$X S_{i, t}: \quad \quad \quad \quad$ Production of sector I

$\mathrm{YDH}_{h, t}$ : $\quad$ Household $\mathrm{H}$ disposable income 

$Y F_{t}:$
Firm income
$Y G_{t}$ :
Government income
$Y H_{h, t}$ :
Household $\mathrm{H}$ income

\subsection{Exogenous Variables}

$C_{i, h, t}^{M I N}:$

Household H minimum consumption of good I (volume)

$e_{t}$ :

Exchange rate (numéraire)

$G_{i, t}$ :

Total public consumption (volume)

$K D_{i, t}$ :

Sector I demand for capital

$K F_{t}$ :

Firm capital

$K G_{t}$ :

Government capital

$K H_{h, t}$ :

Household H capital

$K R O W_{t}$

ROW capital

$P W E_{x, t}$ :

World price of export X (foreign currency)

$P W M_{m, t}$

World price of import M (foreign currency)

$T G_{h, t}:$

Public transfers to households

$T G_{-} F_{t}$

Public transfers to firms

$T G_{-} R O W_{t}$ : Public transfers to ROW

TROW $F_{t}: \quad$ Transfers from ROW to firms

TROW_ $G_{t}$ : Transfers from ROW to government

TROW_ $H_{h, t}$ : Transfers from ROW to households 